\title{
Gluten-Free: Where's the Beef?
}

\author{
Aaron M. Ates ${ }^{1,2, *, \dagger}$ (1) and Jayson L. Lusk ${ }^{3}$ \\ ${ }^{1}$ Berkeley Research Group, College Station, Texas, USA, ${ }^{2}$ Oklahoma State University, Stillwater, Oklahoma, USA and \\ ${ }^{3}$ Department of Agricultural Economics, Purdue University, West Lafayette, Indiana, USA \\ *Corresponding author. Email: AAtes@thinkbrg.com
}

\begin{abstract}
This research seeks to determine effects of rising interest in gluten-free foods on U.S. retail food demand and, ultimately, producer and consumer welfare. Increased gluten-free interest led to a modest reduction in cereals and bakery demand and increases in meat, alcoholic beverages, and food away from home demand. Combining estimated effects with an equilibrium displacement model suggests the reduction in cereal and bakery demand decreases wheat and barley producer profits by US\$7.2 million/year. After accounting for positive demand impacts on other products, results indicate wheat and barley supply is redistributed away from food production into animal production, increasing wheat producer welfare.
\end{abstract}

Keywords: Cereals and bakery; consumer surplus; gluten; gluten free; gluten-free food; producer surplus; social welfare

JEL Classifications: Q11; Q13; D03; D12

Following the publication of popular books such as Wheat Belly (Davis, 2011) and Grain Brain (Perlmutter, 2013), consumer interest in gluten-free products grew. In 2009, about 1,200 new products made gluten-free claims; by 2016, more than 6,100 new product introductions made the claim (Economic Research Service [ERS], 2018a). The zealousness of gluten-free advocates reached such a zenith that parodies, such as "How to Become Gluten Intolerant," emerged (Sears, 2018). Eventually, regulators got involved. The Food and Drug Administration (FDA) reached a final ruling in 2013 regarding the requirements for "gluten-free" labels. ${ }^{1}$

Many requests and suggestions were made to the FDA during the creation of gluten-free labeling standards. A noteworthy request urged the FDA to require a declaration of the presence of gluten on the Nutrition Facts label. Ultimately, the request was deemed outside the scope of the final labeling requirements ruling. Because the purpose of Nutrition Facts labels is to guide consumers in healthy food selections consistent with dietary recommendations (FDA, 2018; Van den Wijngaart, 2002), the denial of the aforementioned request suggests gluten-free food products are not any healthier than products containing gluten. However, results from a survey conducted by the Mintel Group Ltd. (2016) indicate that $73 \%$ of consumers believe gluten-free products to be healthier than their gluten-containing counterparts. Similarly, Navarro (2016) found that consumers perceive food products to be healthier if a gluten-free label is present. This common

\footnotetext{
${ }^{\dagger}$ Present address: 2700 Earl Rudder Freeway S., Suite 4800, College Station, Texas 77845, USA

${ }^{1}$ The labeling of foods as "gluten-free" is voluntary and may be used if the food bearing the claim does not contain an ingredient that is a gluten-containing grain (e.g., spelt wheat); an ingredient that is derived from a gluten-containing grain and that has not been processed to remove gluten (e.g., wheat flour); or an ingredient that is derived from a gluten-containing grain and that has been processed to remove gluten (e.g., wheat starch), if the use of that ingredient results in the presence of 20 parts per million ( $\mathrm{ppm}$ ) or more gluten in the food; or inherently does not contain gluten; and any unavoidable presence of gluten in the food is below $20 \mathrm{ppm}$ gluten (FDA, HHS, 2013).

(C) The Author(s) 2020. This is an Open Access article, distributed under the terms of the Creative Commons Attribution licence (http:/ creativecommons.org/licenses/by/4.0/), which permits unrestricted re-use, distribution, and reproduction in any medium, provided the original work is properly cited.
} 
perception is the leading argument individuals without celiac disease provide for adhering to a gluten-free diet (Mintel Group Ltd., 2016).

Recent consumer surveys indicate that a gluten-free diet has become one of the most popular health food trends in the United States (Miller, 2016). ${ }^{2}$ Interestingly, the prevalence of celiac disease in U.S. citizens remained stable at around 1\% of the population, yet in 2014 an estimated 5.4 million people without gluten intolerance adhered to a gluten-free diet (Choung et al., 2017). ${ }^{3}$ For these reasons, the recent interest in purchasing gluten-free food products is being described as a fad (Reilly, 2016). The gluten-free market is valued at US\$6.6 billion (Aziz, Hadjivassiliou, and Sanders, 2015; Talley and Walker, 2016).

Despite the rising interest in gluten-free foods, there is scant evidence on the impact of this trend on consumer food demand or on farmer welfare. The main objective of this article is to fill this void in the literature.

Historically, U.S. wheat producers and millers relied on the increasing demand for wheat flour to justify further investments. However, per capita flour use began to decrease in 2000 as lowcarbohydrate diets were introduced (e.g., Atkins, 2002; ERS, 2018b). In 2000, per capita wheat flour use was estimated at 146.3 pounds/person and ultimately reached the record low of 132.5 pounds/person in 2011 before rebounding somewhat in more recent years (ERS, 2018b). Acres planted for wheat production fell by 25\% from 1997 to 2010, and would have decreased by nearly $35 \%$ since 1997 to the 2017-2018 projection of 46 million acres (ERS, 2018c; NASS, 2018). The reduction in wheat acreage decreased the U.S. share of global wheat exports from an average of 25\% during 2001-2005 to 15\% in 2017 (ERS, 2018c). While a variety of factors have likely contributed to wheat's demise, the gluten-free diet is one potential culprit. ${ }^{4}$

Wheat is typically sold at the retail level in the form of flour, and is used as a byproduct in many cereal and bakery products (ERS, 2018d). For this reason, we focus on aggregate demand for U.S. cereal and bakery food products. We estimate an Inverse Almost Ideal Demand System (IAIDS) using personal consumption expenditure (PCE) and price index data reported by the Bureau of Economic Analysis (BEA, 2018) along with LexisNexis data collected using the search term "gluten free." Welfare effects are determined by constructing an equilibrium displacement model that links the supply of disaggregated farm commodities to consumer food demands at the retail level. This model relies on the flexibility and demand shock estimates derived from IAIDS estimates.

\section{Data}

\subsection{Expenditure and price data}

The BEA defines consumer spending, or PCEs, as the goods and services purchased by, or on the behalf of, U.S. residents (BEA, 2018). Although annual and quarterly estimates are available, we make use of monthly estimates. It is important to note that monthly PCE values reported on the BEA website are annualized. In other words, the reported PCE for any given month reflects the amount by which it would have changed over a year's time if it had continued to grow at the given rate. For instance, the PCE value reported for March 2017 represents

\footnotetext{
${ }^{2}$ Celiac disease is a digestive disorder triggered by gluten consumption that damages the small intestine. Celiac disease is different from gluten sensitivity or wheat intolerance. While gluten sensitivity leads to symptoms similar to those of celiac disease, it does not damage the small intestine (National Institute of Diabetes and Digestive and Kidney Diseases, 2017).

${ }^{3}$ The number of undiagnosed individuals with celiac disease has decreased over time to roughly $0.3 \%$ of the population.

${ }^{4}$ Other potential factors contributing to the decrease in wheat production are lower relative returns for wheat, changes in government programs that give farmers more planting flexibility, and increased competition in global wheat markets (ERS, 2018c).
} 
the 2017 PCE value if PCE continued to grow at the same rate that it grew in March. Hence, monthly PCE values reported by the BEA are equivalent to monthly consumer spending multiplied by 12 . As a result, we divide (annualized) monthly PCE estimates provided in BEA table 2.4.5U (BEA, 2007) by 12 to recover monthly expenditures for the food products discussed below from January 2004 to July 2018.

The BEA provides U.S. food expenditure information at aggregated and disaggregated levels. This allows total food expenditures to be calculated by summing the aforementioned monthly expenditures of various food groups: (1) cereal and bakery foods, ${ }^{5}(2)$ meat, (3) dairy products, (4) eggs, (5) fruits and vegetables, (6) food away from home, (7) alcoholic beverages, (8) nonalcoholic beverages, and (9) "other" foods. ${ }^{6}$ By dividing each of the food group expenditures by total food expenditures, we calculate the food group expenditure shares. This is done for all nine food products (categories). Following Okrent and Alston (2011), we divide product expenditures by associated price indexes reported by the BEA (BEA, 2017a) to construct implicit quantity indexes. The annual mean expenditure shares can be found in Table 1. Price and quantity indexes are provided in Tables A1 and A2 in Appendix A.

\subsection{Gluten-free index}

Significant literature analyzing demand shifters exists, primarily in analyses of meat demand (Tonsor and Olynk, 2011). Examples of demand shifters include effects of health- and diet related-information (Adhikari et al., 2006; Brown and Schrader, 1990; Chang and Kinnucan, 1991; Kinnucan et al., 1997; Rickertsen, Kristofersson, and Lothe, 2003), food safety and product recall news (Burton and Young, 1996; Marsh, Schroeder, and Mintert, 2004; Piggott and Marsh, 2004), and advertising expenditures (Brester and Schroeder, 1995; Kinnucan et al., 1997; Park and Capps, 2002; Piggott et al., 1996; Rickertsen, 1998).

As indicated by Just (2001), it is not uncommon for media indexes to be used as demand shifters. In fact, Brown and Schrader (1990), Chang and Kinnucan (1991), Burton and Young (1996), Kinnucan et al. (1997), Rickertsen, Kristofersson, and Lothe (2003), Marsh, Schroeder, and Mintert (2004), and Piggott and Marsh (2004) search articles printed in popular newspapers and/or journals for specific verbiage to create media indexes to use as shifters of food demand. Using the LexisNexis database (academic version), we follow these studies and search the top 50 English Language newspapers in circulation from January 2004 to July 2018 for articles containing the verbiage "gluten free."

\footnotetext{
${ }^{5}$ Cereals and bakery products contain the following: wheat flour (except flour mixes), wheat mill products (other than flour and mill feed: wheat germ, wheat bran, etc.), whole and degermed cornmeal for human consumption, corn flour, grits and hominy (except for brewers' use), other corn mill products, flour and other grain mill products, head rice not packaged with other ingredients, head rice packaged with other ingredients, breakfast cereals and related products, macaroni and noodle products (purchased) packaged with other ingredients (not canned or frozen), packaging purchased macaroni and noodle products with other purchased ingredients, corn for feed or processing (except frozen and canned), cash receipts, soy flour and grits, flour mixes and dough, dry pasta, bread (white, wheat, rye, others) including frozen, rolls (bread type), muffins, bagels, and croissants, soft cakes (except frozen), pies (fruit, cream, and custard) except frozen, other sweet goods (except frozen), commercial bakeries, frozen cakes, frozen pies, other frozen pastries, saltine crackers and all other crackers, biscuits, and related products, cookies, wafers, ice cream cones, and cups (except frozen) (BEA, 2007).

${ }^{6} \mathrm{PCEs}$ and associated price indexes are associated with a line number and series name in BEA tables 2.4.5U and 2.4.4U, respectively. The corresponding series IDs are as follows: (1) cereal and bakery-DCBPRC, (2) meat-DMAPRC, (3) dairy products - sum of DMILRC and DDAIRC, (4) eggs_-DGGSRC, (5) fruits and vegetables — sum of DFRURC, DVEGRC, and DPFVRC, (6) food away from home-DFSARC, (7) alcoholic beverages-DAOPRC, (8) nonalcoholic beverages—DNBVRC, and (9) "other" foods-sum of DFATRC, DSWERC, DOFDRC, and DFFDRC (BEA, 2017a, 2017b). The line numbers are as follows: (1) cereal and bakery—74, (2) meat—77, (3) dairy products—sum of 84 and 85, (4) eggs-86, (5) fruits and vegetables — sum of 89, 90, and 91, (6) food away from home-228, (7) alcoholic beverages—97, (8) nonalcoholic beverages-94, and (9) "other" foods-sum of $87,92,93$, and 101 . For food groups containing more than one price index, an expenditure-driven weighted average is used to create a single price index.
} 
Table 1. Average annual food expenditure shares

\begin{tabular}{|c|c|c|c|c|c|c|c|c|c|}
\hline Year & $\begin{array}{l}\text { Cereal and } \\
\text { Bakery } \\
(\%)\end{array}$ & $\begin{array}{c}\text { Meat } \\
(\%)\end{array}$ & $\begin{array}{c}\text { Dairy } \\
(\%)\end{array}$ & $\begin{array}{l}\text { Eggs } \\
(\%)\end{array}$ & $\begin{array}{c}\text { Fruits and } \\
\text { Vegetables } \\
(\%)\end{array}$ & $\begin{array}{c}\text { Food Away } \\
\text { from Home } \\
(\%)\end{array}$ & $\begin{array}{c}\text { Alcoholic } \\
\text { Beverages } \\
(\%)\end{array}$ & $\begin{array}{c}\text { Nonalcoholic } \\
\text { Beverages } \\
(\%)\end{array}$ & $\begin{array}{c}\text { Other } \\
\text { Foods } \\
(\%)\end{array}$ \\
\hline 2004 & 8.53 & 9.71 & 4.25 & 0.62 & 6.35 & 44.36 & 7.98 & 6.01 & 12.19 \\
\hline 2005 & 8.44 & 9.72 & 4.21 & 0.64 & 6.43 & 44.64 & 7.79 & 6.03 & 12.11 \\
\hline 2006 & 8.36 & 9.38 & 4.18 & 0.66 & 6.34 & 45.07 & 7.82 & 6.05 & 12.13 \\
\hline 2007 & 8.32 & 9.35 & 4.34 & 0.72 & 6.35 & 45.04 & 7.73 & 6.02 & 12.13 \\
\hline 2008 & 8.56 & 9.44 & 4.46 & 0.75 & 6.46 & 44.57 & 7.62 & 5.98 & 12.17 \\
\hline 2009 & 8.68 & 9.59 & 4.30 & 0.71 & 6.58 & 44.17 & 7.81 & 5.92 & 12.24 \\
\hline 2010 & 8.56 & 9.57 & 4.28 & 0.71 & 6.59 & 44.27 & 8.07 & 5.82 & 12.15 \\
\hline 2011 & 8.58 & 9.59 & 4.40 & 0.73 & 6.65 & 44.28 & 7.98 & 5.74 & 12.05 \\
\hline 2012 & 8.46 & 9.39 & 4.30 & 0.71 & 6.59 & 45.02 & 8.02 & 5.60 & 11.91 \\
\hline 2013 & 8.47 & 8.82 & 4.27 & 0.70 & 6.79 & 45.66 & 7.92 & 5.41 & 11.95 \\
\hline 2014 & 8.22 & 8.95 & 4.26 & 0.70 & 6.70 & 46.37 & 7.87 & 5.23 & 11.70 \\
\hline 2015 & 8.02 & 8.34 & 4.15 & 0.68 & 6.60 & 47.67 & 7.88 & 5.14 & 11.52 \\
\hline 2016 & 7.85 & 8.09 & 3.99 & 0.65 & 6.48 & 48.46 & 7.91 & 5.07 & 11.50 \\
\hline 2017 & 7.55 & 9.26 & 3.90 & 0.67 & 5.96 & 48.55 & 7.35 & 5.01 & 11.76 \\
\hline 2018 & 7.56 & 9.22 & 3.88 & 0.67 & 5.90 & 48.80 & 7.33 & 4.97 & 11.68 \\
\hline
\end{tabular}

Unlike Kinnucan et al. (1997), our index does not represent "net-publicity" by differentiating between positive and negative information. This distinction is made for a few reasons. The first, and most obvious, is that all gluten-free is anti-gluten. If this approach was adopted, indexes would be negative for all months and inaccurately portray changing interest in gluten-free over time. Moreover, discrimination between positive and negative information as portrayed by the media can be highly subjective (Liu, Huang, and Brown, 1998; Mazzocchi, 2006; Smith, van Ravenswaay, and Thompson, 1988; Verbeke and Ward, 2001). For these reasons, the glutenfree index is defined as the number of articles meeting aforementioned requirements in a given month.

Data were collected on a monthly basis, yielding 175 observations. A graph of gluten-free indexes from January 2004 to July 2018 is shown in Figure 1. LexisNexis data show steady, rising media coverage of gluten-free until mid-2014, after which coverage continues increasing, albeit at a decreasing rate.

\section{Demand estimation}

We first seek to determine the effect of the interest in gluten-free on food demand in the United States-specifically of food products inherently containing gluten. To do so, we estimate the changes in cereals and bakery food expenditure shares, as well as eight other foods.

The implementation of an inverse system of demands, where prices are a function of quantities, provides an alternative and fully dual approach to ordinary demand system(s) (e.g., Almost Ideal Demand System, AIDS). Inverse demands suggest food quantities are exogenous (supply is inelastic), and price must adjust to establish a market equilibrium. Specifying prices as a function of quantities is motivated by the perishability of many foods now consumed and, consequently, 


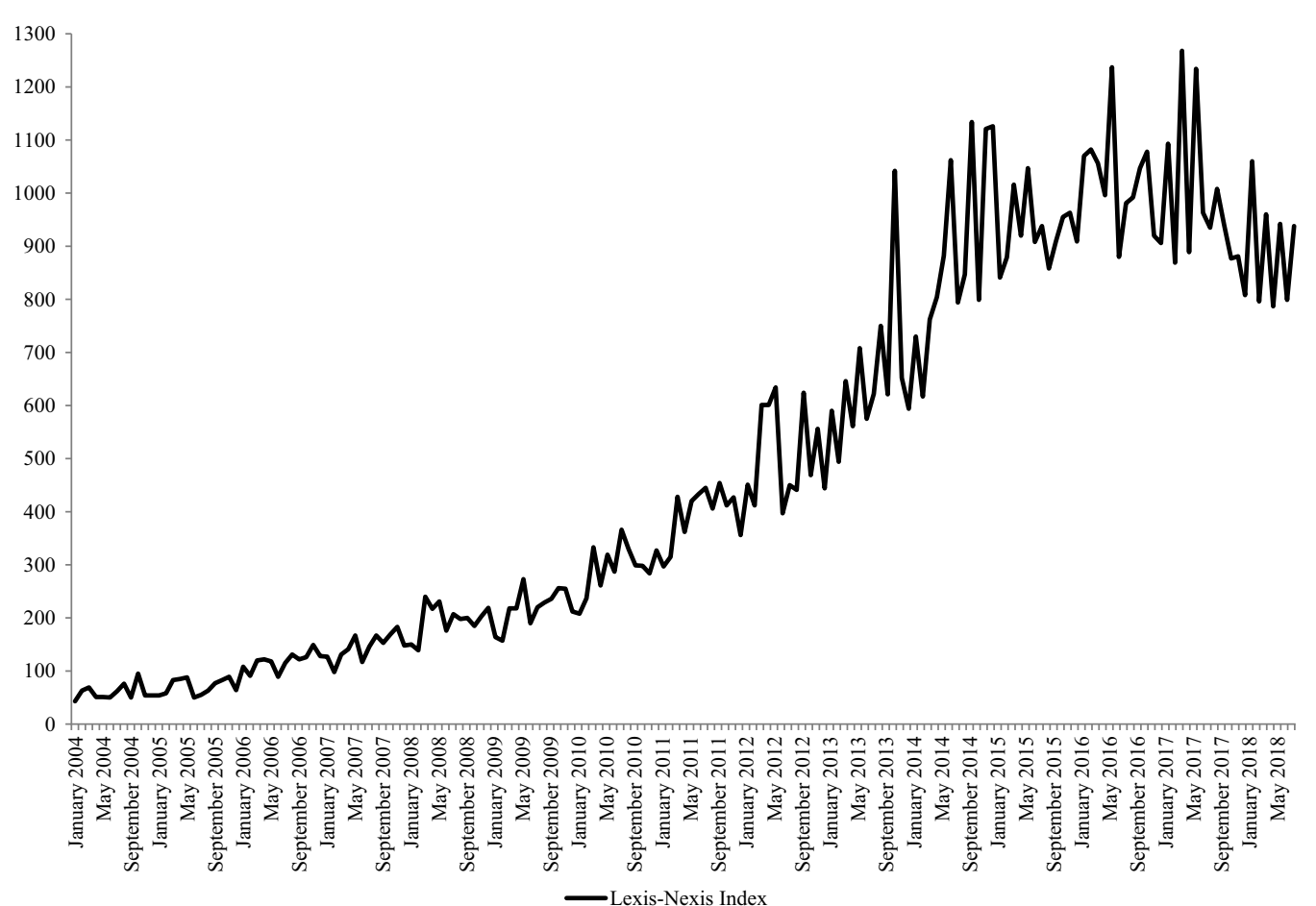

Figure 1. Monthly gluten-free index, 2004 to 2018.

limited storage, by the biological lag inherent in the production of most food products and byproducts sold in the retail setting (Piggott and Marsh, 2010). Because of the biological lag, many food products are essentially fixed in quantity in the short run (Christensen and Manser, 1977; Huang, 1988) and the application of an inverse demand systems approach is warranted (Brown, Le, and Seale, 1995; Chambers and McConnell, 1983; Holt and Goodwin, 1997; Huang, 1988).

The IAIDS proposed by Eales and Unnevehr (1994) is defined as

$$
w_{i t}=\alpha_{i}+\sum_{j=1}^{n} \gamma_{i j} \ln x_{j t}+\beta_{i} \ln Q+\sum_{l=0}^{L} \theta_{i l} G F I_{l t}+\rho_{i} \text { Trend }
$$

where

$$
\ln Q=\alpha_{0}+\sum_{j=1}^{n} \alpha_{j} \ln x_{j t}+\frac{1}{2} \sum_{i=1}^{n} \sum_{j=1}^{n} \gamma_{i j} \ln x_{i t} \ln x_{j t},
$$

and $w_{i t}$ represents the expenditure share of food $i$ in month $t\left(w_{i t}=\frac{p_{i t} x_{i t}}{M}\right), M$ represents total food expenditures, $i=1, \ldots, 9$ representing cereal and bakery products, meat, dairy, eggs, fruits and vegetables, food away from home, alcoholic beverages, nonalcoholic beverages, and other foods, respectively, $t=1, \ldots, 175, x_{i t}$ represents quantity of food $i$ demanded in month $t$, $G F I_{t}$ represents the number of articles printed in the top 50 English language newspapers in the United States in time $t$ containing the verbiage "gluten free" lagged $l$ months, Trend is a time trend, and parameters to be estimated are $\alpha_{0}, \alpha_{i}, \gamma_{i j}, \beta_{i}$ (Eales and Unnevehr, 1994), $\theta_{i}$, and $\rho_{i}$. 
The specification includes an index of interest in gluten-free food (via LexisNexis), much like the inclusion of a BSE consumer awareness indicator variable by Burton and Young (1996). To ensure this index is indeed measuring (and representing) the popularity and effect of interest in gluten-free on food demand, rather than just an overall trend, a time trend is also included. ${ }^{7}$

The nine demand equations represented by equation (1) are estimated as a system. One equation is dropped in the estimation to avoid singularity (we drop the "other" food category). The parameters of the omitted equation are recovered using Engel aggregation (adding up) restrictions. Typical demand restrictions of homogeneity, symmetry, and aggregation are imposed and treated as maintained hypotheses. ${ }^{8}$ Often, the $\alpha_{0}$ parameter is difficult to estimate and may cause convergence issues, leading to difficulties in identifying parameter values. To alleviate such issues, this parameter is set to zero. The models are estimated using iterative seemingly unrelated regressions (ITSUR).

\subsection{Estimation strategy}

The empirical analysis is completed in several steps. First, models are estimated without an index in order to obtain starting values. Because of the nonlinearity of the system, it is possible for models to converge at different local optimums. The use of these starting values for various estimations, discussed subsequently, ensures that all models converge at the same local optimum.

Starting values are used to estimate equation (1) with the gluten-free index. The possibility of lagged effects is considered by sequentially including lag lengths and calculating necessary test statistics. Because of the dynamic nature of the model and the possibility of autocorrelation, Wald tests are used. ${ }^{9}$ Because lagged values of the index are warranted, this suggests information obtained through media has an effect for the number of lagged months on food consumption. Consequently, the possibility of autocorrelation is a concern. ${ }^{10}$

With time series data, the errors in equation (1) may not be serially independent, instead following a vector autoregressive scheme of order $k$. Moschini and Moro (1994) note several options for estimating the structural parameters in equation (1) along with autocorrelation terms. Similarly to Holt and Goodwin (1997) and Piggott et al. (1996), we follow Anderson and Blundell $(1982,1983)$ by estimating less restrictive $(n-1) \times(n-1)$ autocorrelation matrix(es) of the general dynamic model:

$$
\varepsilon_{i t}=\sum_{j}^{n-1} \delta_{k, i j} \varepsilon_{i, t-k}+v_{i t}
$$

\footnotetext{
${ }^{7}$ When failing to include a time trend, the sensitivity of results is worth mentioning. Not only is the number of required lags different, but so is the autoregressive scheme of the error term. This results in opposite signs for some gluten-free index parameter estimates, and ultimately gluten-free flexibilities with opposite signs and different magnitudes. For instance, the cereal and bakery gluten-free flexibility is positive when no time trend is included and the meat gluten-free flexibility is smaller than when a time trend is included. This finding, and results presented later in the manuscript, indicates the necessity of a time trend.

${ }^{8} \mathrm{Necessary}$ adding up, homogeneity, and symmetry demand conditions that lead to parameter restrictions of the expenditure function specification include $\sum_{i=1}^{n} \alpha_{i}=1, \sum_{j=1}^{n} \gamma_{i j}=0, \sum_{i=1}^{n} \beta_{i}=0, \sum_{i=1}^{n} \theta_{i}=0, \sum_{i=1}^{n} \rho_{i}=0, \sum_{i=1}^{n} \gamma_{i j}=0$, and $\gamma_{i j}=\gamma_{j i}$.

${ }^{9}$ For each lagged value added, a Wald test is used to determine if the coefficients are jointly different from zero. If the absolute value of the resulting test statistic is greater than the critical value, an additional lagged value is added. This process is repeated until the absolute value of the test statistic is less than the critical value, indicating the optimal lag length is the last lag length considered for which the joint hypothesis test is rejected.

${ }^{10} \mathrm{An}$ error term, $\varepsilon_{i t}$, is appended to each share equation in the system. The stochastic assumptions used are $E\left(\varepsilon_{i t}\right)=0$ and $E\left(e_{i t} e_{i t}^{\prime}\right)=\Sigma$, where $\Sigma$ is the contemporaneous covariance matrix. Because $\sum_{i} w_{i t}=1, \forall t$, the contemporaneous covariance, is singular. However, this is handled by deleting the equation for "other" foods.
} 
Where $t=1, \ldots, 175,1<k<174$, and $v_{i t}$ are independently, identically distributed normal random errors. Hence, it is not necessary to estimate an $n \times n$ matrix of autocorrelation coefficients, but rather a $(n-1) \times(n-1)$ matrix of autocorrelation coefficients. ${ }^{11}$

Including the necessary lags for each index, we obtain the residuals for $n-1$ share equations using the model specified in equation (1). Residuals are lagged $K$ months and models are reestimated using equation (3) as an error term in equation (1). To test whether each individual equation has autocorrelation, the following hypotheses are conducted:

$$
\mathrm{H}_{1}: \delta_{k, i j}=0, \forall i=j \text { versus } \mathrm{H}_{1 \mathrm{~A}}: \delta_{k, i j} \neq 0, \forall i=j .
$$

Further, to ensure that the less restrictive autocorrelation matrix is necessary, we test that (1) the autocorrelation coefficients are statistically different from each other and zero and (2) the off-diagonal elements in the autocorrelation matrix are statistically different from each other and zero:

$$
\begin{gathered}
\mathrm{H}_{2}: \delta_{k, 11}=\delta_{k, 22}=\ldots=\delta_{k, 88}=0 \text { versus } \mathrm{H}_{2 \mathrm{~A}} \text { : at least one } \delta_{k, i j}(\forall i=j) \neq 0 \\
\mathrm{H}_{3}: \delta_{k, 12}=\delta_{k, 23}=\ldots \delta_{k, 78}=0 \text { versus } \mathrm{H}_{3 \mathrm{~A}}: \text { at least one } \delta_{k, i j}(\forall i \neq j) \neq 0 .
\end{gathered}
$$

The order of the error term autoregressive scheme is represented by the level of $k-1$ for which we fail to reject $\mathrm{H}_{2}$.

\subsection{Flexibility estimates}

Using parameter estimates from equation (1) containing the error term from equation (3), glutenfree flexibilities are estimated as:

$$
f_{i}^{\mathrm{GF}}=\sum_{l}^{L}\left(\frac{\theta_{i l}}{\bar{w}_{i}}\right) \overline{G F I_{l}}
$$

where $f_{i}^{\mathrm{GF}}$ represents the gluten-free flexibility of food $i, \theta_{i l}$ is a parameter estimated in the $i$ th share equation, $\overline{G F L_{l}}$ represents the mean gluten-free index when lag length $l$ is considered, and $\bar{w}_{i}$ represents the mean expenditure share for food $i$.

Following Eales and Unnevehr (1994), we estimate own- and cross-price flexibilities in the following way:

$$
f_{i j}=-\delta_{i j}+\frac{\gamma_{i j}+\beta_{i}\left(w_{j}-\beta_{j} \ln Q\right)}{\bar{w}_{i}},
$$

where $f_{i j}$ represents own- or cross-price flexibilities, $\delta_{i j}$ is the Kronecker delta, $\gamma_{i j}$ and $\beta$ s are model parameters, and $\bar{w}_{i}$ represents the mean expenditure share for food $i$.

We follow Eales and Unnevehr (1994) by describing own- and cross-price flexibilities as the percentage change in the price of the $i$ th good when the quantity demanded increases by $1 \%$. Demand for a commodity is flexible if a $1 \%$ increase in consumption leads to a more than $1 \%$ decrease in the marginal value of that commodity in consumption, and inflexible if an increase in consumption leads to a less than $1 \%$ decrease. Furthermore, goods are termed gross quantity substitutes if their cross-price flexibility is negative, and gross quantity complements if it is positive (Eales and Unnevehr, 1994; Hicks, 1956).

\footnotetext{
${ }^{11}$ The estimated version of the autocorrelation matrix $k$ in equation (3) can be used to recover the elements of the full autocorrelation matrix by using prior information in the form of zero restrictions or other information, as described by Berndt and Savin (1975). However, solving for individual $\delta_{k, i j}$ may not be as important as simply knowing whether they are collectively statistically significant (Piggott et al., 1996).
} 


\section{Equilibrium displacement model}

To determine welfare effects, a partial equilibrium model of the agricultural sector is constructed. Alston (1991) and Wohlgenant (2011) have discussed these models in detail. Okrent and Alston (2012) provided a useful contribution surrounding equilibrium displacement models by linking demand estimates to supply using input-output tables. This article uses the basic framework in Lusk (2017), who built on the Okrent and Alston (2012) framework.

The model used here is the same as in Lusk (2017) except we use the demand flexibilities and demand shocks resulting from the estimates outlined in the previous section. Full details of the model are provided in Lusk (2017) and Okrent and Alston (2012), so they are not repeated here; the key differences in the model used here versus their models are fully described in Appendix B.

\section{Results}

Optimal gluten-free index lag length specifications can be found in Table 2 along with parameter estimates from iterative seemingly unrelated regressions. Results suggest the gluten-free index has an effect for 3 months $(L=3)$ on food demand. Furthermore, test statistics associated with $\mathrm{H}_{2}$ indicate the error term is associated with an autoregressive order scheme of 2 (periods). Autocorrelation matrix coefficients $\left(\delta_{k, i j}\right)$ are shown in Tables A3 and A4 in Appendix A. Uncompensated and compensated own-and cross-price flexibilities are shown in Tables 3 and B1, respectively, and gluten-free index flexibilities and scale flexibilities in Table 4.

Joint autocorrelation tests indicate share equations require separate (nonequal) autocorrelation coefficients $\left(\mathrm{H}_{2}\right)$. A joint test of the off-diagonal elements in autocorrelation matrixes $\left(\mathrm{H}_{3}\right)$ further verifies the appropriateness of following Anderson and Blundell (1982, 1983). Although autocorrelation is not present in each share equation, adding-up restrictions prohibit the deletion of an autocorrelation corrective term. Hence, if we fail to reject $\mathrm{H}_{1}$ for the $i$ th share equation, the autocorrelation coefficient is not statistically different from zero and $\varepsilon_{i t}=v_{i t}$. When $\mathrm{H}_{1}$ is rejected, the autocorrelation is corrected with the $\delta_{k, i j}(i=j)$ estimate.

Coefficients associated with the gluten-free index allow us to determine the effect of interest in gluten-free foods on demand for food-specifically cereal and bakery food products. When estimating cereal and bakery demand, the current period $(L=0)$ is statistically insignificant while all lagged values of the index are significant at the $1 \%$ level. The time trend coefficient is also significant at the $1 \%$ level. This ensures the index is measuring gluten-free interest while indicating the necessity of the time trend. The same results are observed for nonalcoholic beverages as for cereal and bakery products, and similar results are observed for dairy, eggs, and fruits and vegetables. Obverse results are associated with meat, food away from home, and alcoholic beverages, compared to cereal and bakery products. Only lagged values of the index are statistically significant for these food products, and they are associated with positive coefficients and statistically significant time trend coefficients.

It is interesting to note the lack of statistical significance for the current period $(L=0)$ glutenfree index across each share equation in the system of equations, and the associated statistical significance of the time trend. Given the necessity of lagged indexes and statistically significant changes in all food product expenditures over time, it appears the culmination of the popularity and/or media coverage of gluten-free over multiple months would help explain changes in food expenditures. In other words, an increase in gluten-free interest does not have immediate effects on food demand. If the relationship between indexes and expenditures is not invariant to lag length (i.e., positive relationship when $L=0$, but negative when $L=1$ ), the full relationship between each index and food expenditure cannot be determined by coefficient signs alone, and is ambiguous. Because of this, and the reliance on adding-up restrictions to recover coefficients associated with "other" foods, gluten-free flexibility estimates will provide more detailed effects of gluten-free interest on food expenditures. 
Table 2. Iterative seemingly unrelated regressions (ITSUR) estimates of the Inverse Almost Ideal Demand System (IAIDS) model using monthly LexisNexis data

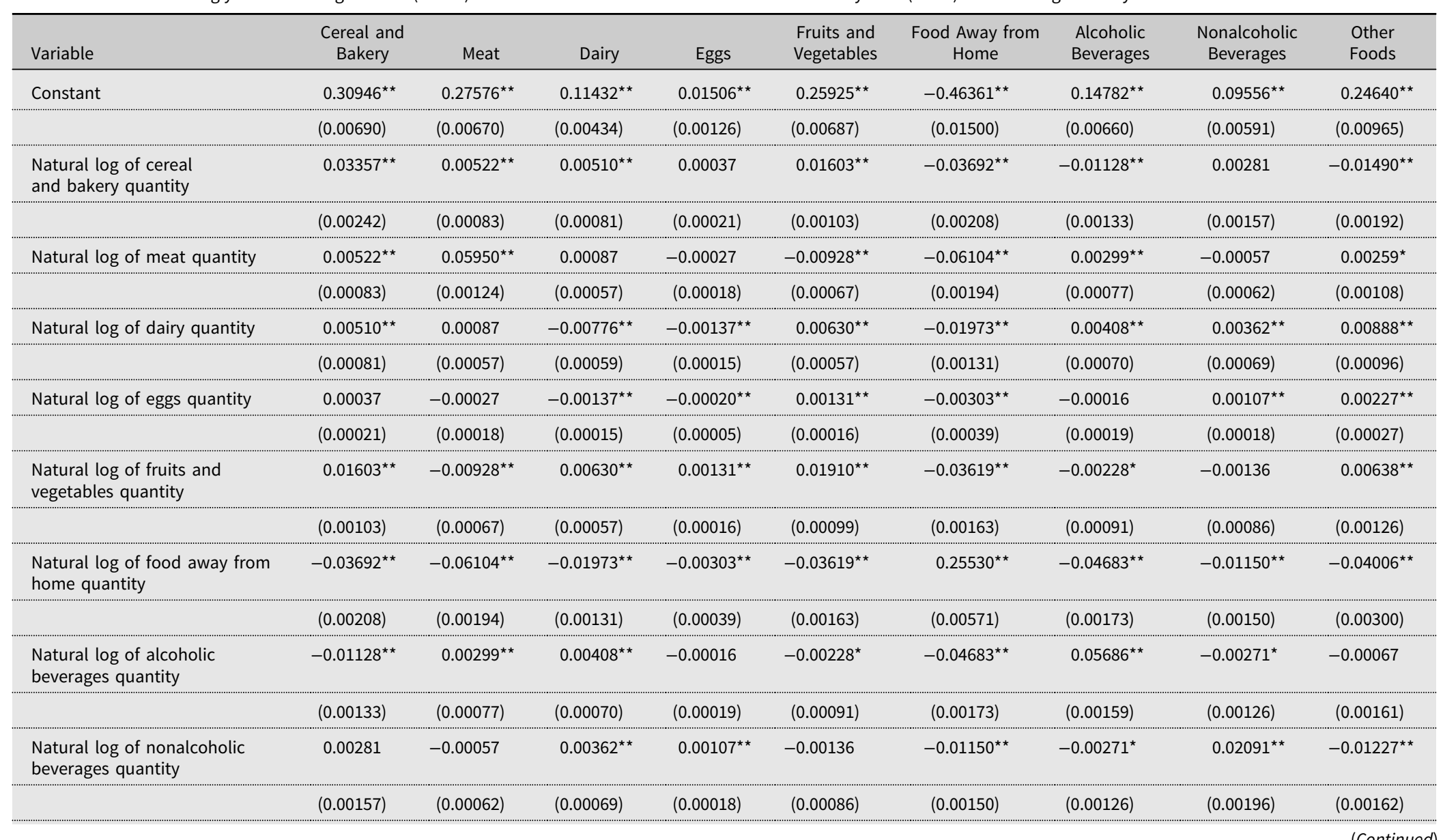


Table 2. (Continued)

\begin{tabular}{|c|c|c|c|c|c|c|c|c|c|}
\hline Variable & $\begin{array}{c}\text { Cereal and } \\
\text { Bakery }\end{array}$ & Meat & Dairy & Eggs & $\begin{array}{l}\text { Fruits and } \\
\text { Vegetables }\end{array}$ & $\begin{array}{c}\text { Food Away from } \\
\text { Home }\end{array}$ & $\begin{array}{l}\text { Alcoholic } \\
\text { Beverages }\end{array}$ & $\begin{array}{c}\text { Nonalcoholic } \\
\text { Beverages }\end{array}$ & $\begin{array}{l}\text { Other } \\
\text { Foods }\end{array}$ \\
\hline \multirow{2}{*}{$\begin{array}{l}\text { Natural log of "other } \\
\text { foods" quantity }\end{array}$} & $-0.01490^{\star \star}$ & $0.00259^{\star}$ & $0.00888^{\star *}$ & $0.00227^{\star *}$ & $0.00638^{\star \star}$ & $-0.04006^{\star *}$ & -0.00067 & $-0.01227^{\star \star}$ & $0.04778^{\star \star}$ \\
\hline & $(0.00192)$ & $(0.00108)$ & $(0.00096)$ & $(0.00027)$ & $(0.00126)$ & $(0.00300)$ & $(0.00161)$ & $(0.00162)$ & $(0.00304)$ \\
\hline \multirow[t]{2}{*}{ Natural log of quantity index } & $-0.0373500^{\star \star}$ & $-0.0215200^{\star *}$ & $-0.0119300^{\star \star}$ & $-0.001270^{\star *}$ & $-0.030900^{\star *}$ & $0.1145140^{\star \star}$ & $0.0041830^{\star \star}$ & 0.0003590 & -0.0160860 \\
\hline & $(0.0016500)$ & $(0.0014800)$ & $(0.0010300)$ & $(0.0002990)$ & $(0.0016700)$ & $(0.0034700)$ & $(0.0015400)$ & $(0.0013300)$ & \\
\hline \multirow[t]{2}{*}{ Gluten-Free $(L=0)$} & -0.0000003 & 0.0000003 & 0.0000002 & 0.0000001 & 0.0000002 & -0.00000002 & -0.00000002 & -0.0000001 & -0.0000003 \\
\hline & $(0.0000003)$ & $(0.0000004)$ & $(0.0000002)$ & $(0.0000001)$ & $(0.0000003)$ & $(0.0000010)$ & $(0.0000003)$ & $(0.0000002)$ & \\
\hline \multirow[t]{2}{*}{ Gluten-free $(L=1)$} & $-0.000002^{\star \star}$ & $0.000003^{\star \star}$ & $-0.000001^{\star \star}$ & $-0.000001^{\star \star}$ & -0.0000004 & $0.000003^{*}$ & $0.000001^{\star \star}$ & $-0.000002^{\star \star}$ & -0.000001 \\
\hline & $(0.0000004)$ & $(0.000001)$ & $(0.0000003)$ & $(0.0000001)$ & $(0.0000004)$ & $(0.000001)$ & $(0.0000003)$ & $(0.0000003)$ & \\
\hline \multirow[t]{2}{*}{ Gluten-free $(L=2)$} & $-0.000002^{\star \star}$ & $0.000004^{\star *}$ & $-0.000002^{\star \star}$ & $-0.000001^{\star \star}$ & $-0.000001^{\star \star}$ & $0.000003^{\star *}$ & $0.000002^{\star \star}$ & $-0.000002^{\star \star}$ & -0.000001 \\
\hline & $(0.0000003)$ & $(0.0000004)$ & $(0.0000002)$ & $(0.0000001)$ & $(0.0000003)$ & $(0.000001)$ & $(0.0000003)$ & $(0.0000002)$ & \\
\hline \multirow[t]{2}{*}{ Gluten-free $(L=3)$} & $-0.000002^{\star *}$ & $0.000003^{\star *}$ & $-0.000001^{\star *}$ & $-0.000001^{\star \star}$ & $-0.000001^{\star \star}$ & $0.000003^{\star *}$ & $0.000001^{\star \star}$ & $-0.000002^{\star *}$ & -0.000001 \\
\hline & $(0.0000003)$ & $(0.0000004)$ & $(0.0000002)$ & $(0.0000001)$ & $(0.0000003)$ & $(0.000001)$ & $(0.0000003)$ & $(0.0000002)$ & \\
\hline \multirow[t]{2}{*}{ Time trend } & $0.0000700^{\star \star}$ & $-0.0000400^{\star \star}$ & $0.0000330^{* *}$ & $0.000016^{\star *}$ & $0.0000510^{\star *}$ & $-0.000040^{\star *}$ & $-0.000070^{\star \star}$ & $-0.000020^{\star \star}$ & 0.0000000 \\
\hline & $(0.187700)$ & $(0.000004)$ & $(0.000003)$ & $(0.000001)$ & $(0.000003)$ & $(0.000010)$ & $(0.000004)$ & $(0.000003)$ & \\
\hline Diagnostic Statistics & Test Statistic & & & & & & & & \\
\hline No trend vs. $L=0$ & $46.47^{\star \star}$ & & & & & & & & \\
\hline$L=1$ vs. $L=0$ & $40.93^{\star \star}$ & & & & & & & & \\
\hline$L=2$ vs. $L=1$ & $21.98^{\star \star}$ & & & & & & & & \\
\hline$L=3$ vs. $L=2$ & $16.17^{\star}$ & & & & & & & & \\
\hline$L=4$ vs. $L=3$ & 15.25 & & & & & & & & \\
\hline
\end{tabular}

*Statistical significance at the $5 \%$ level.

**Statistical significance at the $1 \%$ level.

Note: Standard errors are in parentheses. 
Table 3. Uncompensated own- and cross-price flexibilities using iterative seemingly unrelated regressions (ITSUR) estimates of the Inverse Almost Ideal Demand System (IAIDS) model with monthly data

\begin{tabular}{|c|c|c|c|c|c|c|c|c|c|}
\hline \multirow[b]{2}{*}{ With Respect to } & \multicolumn{9}{|c|}{ Price Flexibility for } \\
\hline & $\begin{array}{c}\text { Cereal and } \\
\text { Bakery }\end{array}$ & Meat & Eggs & Dairy & $\begin{array}{l}\text { Fruits and } \\
\text { Vegetables }\end{array}$ & $\begin{array}{l}\text { Other } \\
\text { Foods }\end{array}$ & $\begin{array}{c}\text { Nonalcoholic } \\
\text { Beverages }\end{array}$ & $\begin{array}{c}\text { Food Away from } \\
\text { Home }\end{array}$ & $\begin{array}{l}\text { Alcoholic } \\
\text { Beverages }\end{array}$ \\
\hline \multirow[t]{2}{*}{ Cereal and bakery } & $-0.7052^{\star \star}$ & -0.0003 & $0.0092^{\star}$ & 0.0520 & $0.1315^{\star \star}$ & $-0.1574^{\star \star}$ & $0.0516^{\star \star}$ & -0.0197 & $-0.1312^{\star \star}$ \\
\hline & $(0.0284)$ & $(0.0097)$ & $(0.0325)$ & (0.0199) & $(0.0182)$ & $(0.0160)$ & $(0.0276)$ & $(0.0053)$ & $(0.0165)$ \\
\hline \multirow[t]{2}{*}{ Meat } & $-0.0204^{\star}$ & $-0.3984^{\star \star}$ & $-0.0726^{\star}$ & $-0.0315^{\star \star}$ & $-0.2319^{\star \star}$ & $-0.0033^{\star \star}$ & $-0.0090^{\star \star}$ & -0.0872 & 0.0482 \\
\hline & $(0.0101)$ & $(0.0114)$ & $(0.0240)$ & $(0.0129)$ & $(0.0112)$ & $(0.0088)$ & $(0.0112)$ & $(0.0040)$ & $(0.0100)$ \\
\hline \multirow[t]{2}{*}{ Eggs } & -0.0011 & -0.0058 & $-1.0318^{\star \star}$ & $-0.0359^{\star \star}$ & $0.0143^{\star *}$ & $0.0174^{\star \star}$ & $0.0190^{\star *}$ & $-0.0035^{\star \star}$ & $-0.0013^{\star \star}$ \\
\hline & $(0.0026)$ & $(0.0019)$ & $(0.0071)$ & $(0.0036)$ & $(0.0029)$ & $(0.0022)$ & $(0.0031)$ & $(0.0010)$ & $(0.0024)$ \\
\hline \multirow[t]{2}{*}{ Dairy } & 0.0194 & $-0.0123^{\star \star}$ & $-0.2154^{\star \star}$ & $-1.2103^{\star \star}$ & $0.0527^{\star \star}$ & $0.0617^{\star \star}$ & 0.0651 & $-0.0197^{\star \star}$ & $0.0572^{\star \star}$ \\
\hline & $(0.0102)$ & $(0.0063)$ & $(0.0226)$ & $(0.0148)$ & $(0.0106)$ & $(0.0083)$ & $(0.0125)$ & $(0.0033)$ & $(0.0090)$ \\
\hline \multirow[t]{2}{*}{ Fruits and vegetables } & $0.1043^{\star *}$ & $-0.1467^{\star \star}$ & $0.1533^{\star \star}$ & $0.0934^{\star *}$ & $-0.7990^{\star \star}$ & $0.0268^{\star \star}$ & -0.0230 & -0.0297 & $-0.0187^{\star}$ \\
\hline & $(0.0149)$ & $(0.0087)$ & $(0.0289)$ & $(0.0168)$ & $(0.0216)$ & $(0.0126)$ & $(0.0185)$ & $(0.0046)$ & $(0.0138)$ \\
\hline \multirow[t]{2}{*}{ Other foods } & $-0.2645^{\star \star}$ & $-0.0160^{\star \star}$ & $0.2953^{\star *}$ & $0.1570^{\star *}$ & $0.0085^{\star \star}$ & $-0.6257^{\star \star}$ & $-0.2173^{\star \star}$ & $-0.0403^{\star \star}$ & $0.0016^{\star \star}$ \\
\hline & $(0.0227)$ & $(0.0114)$ & $(0.0374)$ & $(0.0225)$ & $(0.0209)$ & $(0.0237)$ & $(0.0279)$ & $(0.0066)$ & $(0.0196)$ \\
\hline \multirow[t]{2}{*}{$\begin{array}{l}\text { Nonalcoholic } \\
\text { beverages }\end{array}$} & $0.0093^{\star *}$ & $-0.0189^{\star}$ & $0.1444^{\star \star}$ & 0.0704 & $-0.0472^{\star \star}$ & $-0.1101^{\star \star}$ & $-0.6273^{\star \star}$ & $-0.0115^{\star}$ & -0.0317 \\
\hline & $(0.0186)$ & $(0.0068)$ & $(0.0255)$ & $(0.0164)$ & $(0.0149)$ & $(0.0133)$ & $(0.0347)$ & $(0.0035)$ & $(0.0157)$ \\
\hline \multirow{2}{*}{$\begin{array}{l}\text { Food away from } \\
\text { home }\end{array}$} & -0.4290 & $-0.6532^{\star \star}$ & $-0.4324^{\star \star}$ & $-0.4575^{\star \star}$ & $-0.5426^{\star \star}$ & $-0.3304^{\star \star}$ & $-0.2050^{\star}$ & $-0.4504^{\star \star}$ & $-0.6009^{\star \star}$ \\
\hline & $(0.0257)$ & $(0.0199)$ & $(0.0576)$ & $(0.0317)$ & $(0.0277)$ & $(0.0248)$ & $(0.0266)$ & $(0.0128)$ & $(0.0220)$ \\
\hline \multirow[t]{2}{*}{ Alcoholic beverages } & $-0.1631^{\star \star}$ & 0.0184 & $-0.0336^{\star \star}$ & $0.0797^{\star \star}$ & -0.0641 & $-0.0137^{\star \star}$ & -0.0478 & $-0.0874^{\star \star}$ & $-0.2697^{\star \star}$ \\
\hline & $(0.0160)$ & $(0.0084)$ & $(0.0284)$ & $(0.0170)$ & $(0.0162)$ & $(0.0136)$ & $(0.0229)$ & $(0.0042)$ & $(0.0208)$ \\
\hline
\end{tabular}

*Statistical significance at the $5 \%$ level.

** Statistical significance at the $1 \%$ level.

Note: Standard errors are in parentheses. 
Table 4. Gluten-free media and scale flexibilities using iterative seemingly unrelated regressions (ITSUR) estimates of the Inverse Almost Ideal Demand System (IAIDS) model

\begin{tabular}{|c|c|c|}
\hline Food Product & Gluten-Free Flexibility & Scale Flexibility \\
\hline \multirow[t]{2}{*}{ Cereal and bakery } & $-0.0384^{\star \star}$ & $-1.4502^{\star \star}$ \\
\hline & $(0.0028)$ & $(0.0198)$ \\
\hline \multirow[t]{2}{*}{ Meat } & $0.0533^{\star *}$ & $-1.2332^{\star \star}$ \\
\hline & $(0.0033)$ & $(0.0160)$ \\
\hline \multirow[t]{2}{*}{ Dairy } & $-0.0494^{\star *}$ & $-1.2826^{\star \star}$ \\
\hline & $(0.0039)$ & $(0.0243)$ \\
\hline \multirow[t]{2}{*}{ Eggs } & $-0.1327^{\star \star}$ & $-1.1836^{\star \star}$ \\
\hline & $(0.0071)$ & $(0.0434)$ \\
\hline \multirow[t]{2}{*}{ Fruits and vegetables } & $-0.0182^{\star \star}$ & $-1.4778^{\star \star}$ \\
\hline & $(0.0032)$ & $(0.0259)$ \\
\hline \multirow[t]{2}{*}{ Food away from home } & $0.0100^{\star \star}$ & $-0.7495^{\star \star}$ \\
\hline & $(0.0016)$ & $(0.0076)$ \\
\hline \multirow[t]{2}{*}{ Alcoholic beverages } & $0.0263^{\star *}$ & $-0.9465^{\star \star}$ \\
\hline & $(0.0024)$ & $(0.0197)$ \\
\hline \multirow[t]{2}{*}{ Nonalcoholic beverages } & $-0.0481^{\star \star}$ & $-0.9936^{\star \star}$ \\
\hline & $(0.0027)$ & $(0.0237)$ \\
\hline \multirow[t]{2}{*}{ Other foods } & $-0.0124^{\star *}$ & $-1.1346^{\star *}$ \\
\hline & $(0.0024)$ & $(0.0178)$ \\
\hline
\end{tabular}

${ }^{*}$ Statistical significance at the $5 \%$ level.

${ }^{*}$ Statistical significance at the $1 \%$ level.

Note: Standard errors are in parentheses.

\subsection{Own- and cross-price flexibilities}

Table 3 contains uncompensated own- and cross-price flexibility estimates. All own-price flexibility estimates are statistically different from zero. The own-price flexibilities of cereal and bakery food products, meat, fruits and vegetables, food away from home, alcoholic beverages, nonalcoholic beverages, and "other" foods indicate that these food products are inflexible goods. The cereal and bakery own-price flexibility measurement is not surprising given the wide array of substitutes captured by cross-price flexibilities: meat, eggs, food away from home, alcoholic beverages, and other foods.

Dairy, fruits and vegetables, and nonalcoholic beverages are considered gross quantity complements of cereal and bakery products. Results are consistent with findings from Okrent and Alston (2011). Differences in results pertain to the relationship between cereal and bakery goods with alcoholic beverages; they report alcoholic beverages as a complement to cereal and bakery products.

\subsection{Gluten-free flexibilities}

The gluten-free flexibility measurement is of primary interest. Because (the majority) cereal and bakery foods inherently contain gluten, and nearly 5.4 million Americans have recently adopted the gluten-free lifestyle, it is logical to hypothesize that expenditures of such products would 
significantly decrease as interest in gluten-free foods increases. Although this is a large number of individuals, this faction represents $\sim 1.7 \%$ of the total U.S. population. As a result, we expect gluten-free flexibility estimates to be small.

As shown in Table 4, the cereal and bakery gluten-free flexibility estimate $(-0.0384)$ is statistically significant at the $1 \%$ level. Ceteris paribus, this means a $1 \%$ increase in the gluten-free index is associated with a $0.0384 \%$ decrease in cereal and bakery prices. Thus, the rise in popularity of gluten-free diets has significantly decreased the expenditures of products inherently containing gluten. However, significant effects are not limited to gluten-containing foods. Demand for dairy, eggs, fruits and vegetables, nonalcoholic beverages, and other foods decreases significantly ( $1 \%$ level) as interest in gluten-free increases. Conversely, a positive relationship between gluten-free interest and food away from home and alcoholic beverages is observed at the $1 \%$ significance level. In short, the estimated flexibilities range from -0.133 for eggs to 0.053 for meat, and all are significant at the $1 \%$ level.

Perhaps effects captured by model coefficients and estimated flexibilities should not be a surprise given results recently published in the literature. Take, for example, the lean finely textured beef (LFTB) — otherwise known as pink slime-fiasco in 2012. The media paid extra attention to LFTB, and Yadavalli and Jones (2014) hypothesized that the media portrayal of LFTB would negatively affect the consumption of aggregate meat and beef cuts. However, their parameter estimates indicate that increased media attention did not immediately lead to significant changes in consumer demand across meats or within the beef category. Pork expenditures did not significantly decrease until 2 weeks after news reports of LFTB surfaced, but demand rose the following week. On the fourth week, no significant media effects were observed. Demand for turkey increased 2 weeks after news of LFTB broke, but significant effects on demand disappeared in the third week. Similar results were observed with Prime beef demand. Significant demand effects were not observed until week three, which was followed by decreased demand in week four. In short, Yadavalli and Jones (2014) found effects of LFTB media coverage on meat demand to be delayed and short-lived. The use of monthly data in this study prohibits the determination of weekly or daily effects of gluten-free interest on food demand. However, results from Yadavalli and Jones (2014) provide merit to the possibility of delayed media effects on food demand.

Robert Atkins published a book in 1972 advocating a low-carbohydrate diet he used to treat patients in the 1960s (see Atkins, 1972). Around the time it was rewritten in 2002 (see Atkins, 2002), the "Atkins diet" became increasingly popular. Similarly to this study, Tonsor, Mintert, and Schroeder (2010) created a media index centered on the Atkins diet, ${ }^{12}$ amongst other factors, to determine changes in meat demand. Because they focus on media information impacts on meat demand, effects on various meat products (e.g., beef, pork, and poultry) are evaluated. Results from their study indicate a positive relationship between net positive information associated with the Atkins diet (a high-protein, low-carbohydrate diet) and the demand for beef. ${ }^{13}$ While separate meat categories are not considered in this study, we also find positive, significant effects of increased gluten-free interest on meat demand. It can be argued that the obsession with a gluten-free diet, especially for those who do not have celiac disease or gluten intolerance (i.e., 5.4 million Americans), is the present-day equivalent to the previous obsession with the Atkins diet. After all, the two diets represent the same guidelines (decreased carbohydrate consumption).

\footnotetext{
${ }^{12}$ They create a net Atkins index by obtaining articles from the LexisNexis database and classifying articles by the positive or negative information presented. Positive articles are defined as those promoting low-carbohydrate diets and negative articles are those focusing on potential adverse health impacts of such diets. The index is created by subtracting the number of negative articles from that of positive articles in a given quarter.

${ }^{13}$ Using quarterly data, Tonsor, Mintert, and Schroeder (2010) estimate compensated elasticities of demand for beef, pork, poultry, and other foods with respect to the net-positive Atkins diet index to be $0.0077,-0.0047,-0.0036$, and 0.001 , respectively. Only the beef elasticity is statistically significant. Our estimated gluten-free flexibility for all meats, 0.0533 , is significant at the $1 \%$ level.
} 


\subsection{Welfare effects}

The equilibrium displacement model calculates effects of changes relative to an initial equilibrium. This means we analyze effects of changes in retail demand for food products attributed to increased interest in gluten-free. Two scenarios are considered. The first scenario contains a partial impact of gluten-free interest where only a shock to cereal and bakery demand is considered, and the second scenario contains the full impact (of gluten-free interest) where all estimated demands are shocked.

Because of the biological lag associated with the production of commodities and the subsequent consumption of final retail food products, we evaluate changes in annual producer welfare. By summing the number of articles containing the phrase "gluten-free" each year, we estimate average annual changes in the gluten-free index to be $25 \%$ (see Table A5 in Appendix A). For this reason, we use flexibility estimates presented in Table 4 to reflect changes in producer and consumer welfare for a $25 \%$ increase in newspaper articles rather than a $1 \%$ increase.

Producer surplus/deficit is equal to economic profits/losses, ignoring fixed costs, which do not vary with the volume of production. It should be noted that producer welfare changes are accrued to all producers of the commodity in question and the suppliers of inputs to producers (Just, Hueth, and Schmitz, 2005). However, further delineating the incidence of these effects for the farming supply chain would require expanding the model to include the supply and demand of each input (Lusk, 2017). As a result, producer welfare estimates are presented with the understanding that changes are aggregated to capture upstream firms in addition to farmers.

Compensating variation is used to express changes in consumer welfare. This represents the amount of money that would need to be given to consumers to make them as well off as they were before the demand shock. It includes any extra expenditures consumers make following the demand shock and an estimate of the loss that occurs from consumers choosing a less desirable bundle of products. Although it would be nice to focus on compensating variation for specific products, only an aggregate change in compensating variation can be calculated across all goods because we have multiple demand curves (Wohlgenant, 2011). Because of this, we sum estimated changes in compensating for variation across goods.

\subsubsection{Scenario 1: Partial impact}

While Table 5 shows changes in producer surplus for all commodities included in this study, we primarily focus on changes in wheat and barley producer profits in this scenario because only cereal and bakery shocks are considered. Results indicate wheat and barley producer profits decrease by US $\$ 6.77$ million/year and US $\$ 455,000$ million/year, respectively, from increased interest in gluten-free. In addition, flexibility estimates indicate meat is a substitute for cereal and bakery foods. Ultimately, this translates to increases in profits for cattle, hog, and poultry producers.

An increase of US\$562 million in consumer welfare is observed when summing estimated changes in compensating variation across all goods. Combining changes in consumer and producer surplus attributed to decreased demand for cereal and bakery products when newspaper articles on gluten-free increase by $25 \%$ suggests a net benefit in social welfare of US $\$ 1.5$ billion. These results are presented in Table 6 .

We are not naïve to the fact that changes in demand for cereal and bakery foods at the retail level will also affect the consumption of other goods. After all, estimated cross-price flexibilities indicate that many foods are considered substitutes, for example, meat. As shown through results of implementing a partial impact, changes in retail food demand for all products will likely impact producer profits. However, producers must decide which crops to produce well in advance of planting and it may take years for producers to transition practices and produce alternative commodities because of crop-specific growing seasons. This poses an interesting conundrum 
Table 5. Partial impact effects of gluten-free interest on commodity prices and producer welfare from a shock to cereal and bakery retail demand

\begin{tabular}{|c|c|c|}
\hline Product & Change in Price $\left(\widehat{w}_{k}\right)$ & $\begin{array}{l}\text { Change in Producer Welfare } \\
\text { (million US\$) }\end{array}$ \\
\hline Vegetables and melons & -0.0009 & -13.53 \\
\hline Fruit and tree nuts & 0.0003 & 7.95 \\
\hline Sugarcane and sugar beet & 0.0072 & 18.60 \\
\hline Peanuts & 0.0074 & 8.09 \\
\hline Fish & 0.0108 & 186.61 \\
\hline Marketing inputs & -0.0000003 & -0.33 \\
\hline Soybeans & -0.0002 & -7.76 \\
\hline Corn & 0.0012 & 60.48 \\
\hline Wheat & -0.0006 & -6.77 \\
\hline Rice & -0.0006 & -1.72 \\
\hline Barley & -0.0005 & -0.45 \\
\hline Oats & 0.0012 & 0.24 \\
\hline Sorghum & 0.0003 & 0.42 \\
\hline Cattle & 0.0067 & 290.96 \\
\hline Hogs & 0.0084 & 142.54 \\
\hline Dairy & 0.0019 & 65.28 \\
\hline Poultry & 0.0045 & 141.20 \\
\hline Eggs & 0.0050 & 41.51 \\
\hline Total $\triangle P S$ & & 993.33 \\
\hline
\end{tabular}

Abbreviations: PS, producer surplus.

surrounding the production practices and welfare of various commodity producers that can only be answered by considering the full impact of increased interest in gluten-free.

\subsubsection{Scenario 2: Full impact}

As indicated through own- and cross-price flexibility estimates, changes in quantity consumed affect the prices of other goods available for purchase. In other words, changes in preferences for particular goods affect the demand for their substitutes and complements. Scenario 2 investigates changes in producer and consumer welfare attributed to effects of rising interest in glutenfree on retail demand for all foods.

Changes in producer welfare are presented in Table 7. In this scenario, wheat and barley producers have not experienced decreases in profits as a result of increased interest in gluten-free foods. Instead, results suggest wheat and barley producer profits have increased by US $\$ 12.25$ million per year and US\$2.2 million/year, respectively. Given the negative relationship between retail demand for gluten-based food products and the media index, these results seem counterintuitive at first glance. However, results indicate that the outward shifts in meat and food away from home demand attributed to increases in gluten-free articles (more than) compensate for the inward shift in cereal and bakery demand. In what follows, we trace the flow of these competing demand shifts through the model. 
Table 6. Partial impact effects of gluten-free interest on retail prices, quantity, and consumer welfare from a shock to cereal and bakery retail demand

\begin{tabular}{|c|c|c|c|}
\hline Product & Change in Price (\%) & Change in Quantity (\%) & $\begin{array}{l}\text { Welfare Change } \\
\text { (million US\$/year) }\end{array}$ \\
\hline Cereal and bakery & 0.00003 & -0.02001 & \\
\hline Meat & 0.00235 & 0.01021 & \\
\hline Eggs & 0.00226 & 0.00031 & \\
\hline Dairy & 0.00050 & 0.00466 & \\
\hline Fruits and vegetables & -0.00015 & -0.00215 & \\
\hline Other food & 0.00027 & 0.00952 & \\
\hline Nonalcoholic beverages & 0.00004 & -0.00423 & \\
\hline Food away from home & 0.00019 & -0.00862 & \\
\hline Alcoholic beverages & 0.00002 & 0.03236 & \\
\hline Total $\triangle C V$ & & & 561.66 \\
\hline Total $\Delta S W$ & & & $1,494.98$ \\
\hline
\end{tabular}

Abbreviations: CV, compensating variation; SW, social welfare.

Table 7. Full impact effects of gluten-free interest on commodity prices and producer welfare from a shock to all food demand

\begin{tabular}{|c|c|c|}
\hline Product & $\begin{array}{l}\text { Change in Price } \\
\left(\widehat{w}_{k}\right)(\%)\end{array}$ & $\begin{array}{l}\text { Change in Producer Welfare } \\
\text { (million US\$) }\end{array}$ \\
\hline Vegetables and melons & -0.0078 & -112.70 \\
\hline Fruit and tree nuts & -0.0017 & -46.94 \\
\hline Sugarcane and sugar beet & 0.0155 & 40.40 \\
\hline Peanuts & 0.0172 & 18.83 \\
\hline Fish & 0.0803 & $1,410.82$ \\
\hline Marketing inputs & -0.0000009 & -1.10 \\
\hline Soybeans & -0.0028 & -92.90 \\
\hline Corn & 0.0090 & 459.76 \\
\hline Wheat & 0.0011 & 12.25 \\
\hline Rice & 0.0000 & 0.01 \\
\hline Barley & 0.0024 & 2.20 \\
\hline Oats & 0.0117 & 2.45 \\
\hline Sorghum & 0.0032 & 4.56 \\
\hline Cattle & 0.0443 & $1,965.98$ \\
\hline Hogs & 0.0550 & 953.69 \\
\hline Dairy & 0.0002 & 5.42 \\
\hline Poultry & 0.0257 & 809.53 \\
\hline Eggs & 0.0283 & 237.98 \\
\hline Total $\triangle P S$ & & $5,670.27$ \\
\hline
\end{tabular}


Input-output tables (produced by Okrent and Alston, 2012) show that $38 \%$ of the total cost of grain production was allocated to cereal and bakery products, $1.3 \%$ to fruits and vegetables, and $38 \%$ to other foods. Not only are these foods associated with negative flexibilities, but model results also indicate that the portion of wheat and barley allocated to food production decreased $(0.0034 \%)$. Instead, a larger percentage $(0.034 \%)$ was used in animal feed. In other words, the costs of grain production were being allocated differently-to animal production.

From 2004 to 2017, the supply of livestock increased, and producers of these products experienced increases in profits (most likely from increases in retail meat demand). Moreover, $16 \%$ of the cost of cattle production, $19 \%$ of other livestock, $14 \%$ of poultry and egg, and $23 \%$ of dairy farming production are attributed to food away from home. Interestingly, food away from home is associated with a positive flexibility, and about $17 \%$ of the remaining aforementioned cost of grain production is attributed to food away from home.

In short, this information suggests that the percentage of wheat that was once used to produce cereal and bakery products has decreased and is now being redistributed and used as feed in animal production. This results in a final product: meat. The extent to which grain production costs have changed is difficult to quantify; however, results suggest a portion of grain production costs are now indirectly allocated to meat, eggs, and dairy retail products through animal productionwhich was not the case beforehand-and a larger portion of these costs is allocated to alcoholic beverages. This also implies that a larger portion of aforementioned cattle, other livestock, poultry and egg, and dairy farming production costs have been allocated to food away from home. These changes have occurred to satisfy the decreased demands for cereal and bakery products and increased demand for meat and food away from home substitutes. Thus, it appears as though the decreased demand for cereal and bakery products at the retail level and increased demand for meat, food away from home, and alcoholic beverages have benefitted not only consumers, but also wheat, barley, cattle, pork, dairy, poultry, and egg producers.

As suggested by flexibility estimates, meat producers receive the largest increases in profit (US $\$ 3.7$ billion/year). Specifically, cattle producers have received the largest increase, US $\$ 1.97$ billion/year, and poultry producers the smallest increase, US $\$ 809$ million/year. Only vegetable and melon, fruit and tree nut, and soybean producers have been negatively impacted by increased interest in gluten-free. Vegetable and melon producers have experienced the greatest profit losses, upward of US\$112 million/year. In total, producer surplus is estimated to be US $\$ 5.67$ billion/year.

Table 8 shows the sum of compensating variation across all nine retail food products. Estimates indicate that consumers experience a benefit of US $\$ 3$ billion/year when the number of articles on gluten-free increases by $25 \%$. Combining changes in consumer and producer welfare results in social economic welfare change. As indicated in Table 8 , social welfare increases by US $\$ 8.8$ billion/year-assuming the number of gluten-free-related newspaper articles increases by $25 \%$ each year.

\section{Conclusions}

There has been much discussion and hype regarding gluten-free foods in recent years. Results suggest expenditures for cereal and bakery products decreased as the popularity of the gluten-free topic increased. The delayed effects of interest in gluten-free (as captured by IAIDS coefficients) are similar to findings by Yadavalli and Jones (2014). Moreover, the effect of increased gluten-free interest is observed in expenditures for other food products not inherently containing gluten as well as respective changes in producer surplus. To satisfy changing consumer preferences, the use of wheat and barley supplied by producers is redistributed away from food production into 
Table 8. Full impact effects of gluten-free interest on retail prices, quantity, and consumer welfare from a shock to all food demand

\begin{tabular}{lccc}
\hline Product & Change in Price (\%) & $\begin{array}{c}\text { Change in } \\
\text { Quantity (\%) }\end{array}$ & $\begin{array}{c}\text { Welfare Change } \\
\text { (million US\$/year) }\end{array}$ \\
\hline Cereal and bakery & 0.00019 & -0.03719 & \\
\hline Meat & 0.01595 & 0.06341 \\
\hline Eggs & 0.01325 & -0.04103 \\
\hline Dairy & 0.00028 & 0.01047 \\
\hline Fruits and vegetables & -0.00214 & -0.01267 \\
\hline Other food & 0.00056 & 0.02351 \\
\hline Nonalcoholic beverages & 0.00001 & -0.03004 & \\
\hline Food away from home & 0.00117 & -0.03546 & \\
\hline Alcoholic beverages & 0.00002 & 0.13973 & \\
\hline Total $\triangle C V$ & & & $3,161.98$ \\
\hline Total $\triangle S W$ & & & $8,832.24$ \\
\hline
\end{tabular}

Abbreviations: CV, compensating variation; SW, social welfare.

animal production. These and other market-equilibrating adjustments result in minimal retail food price changes.

Flexibility estimates suggesting increases in expenditures for food products not inherently containing gluten yet bearing the label due to the labeling laws is not surprising considering annual retail snack and meat gluten-free sales totaled approximately US $\$ 4.4$ billion and US $\$ 2.5$ billion alone in 2016 (Mintel Group Ltd., 2016). ${ }^{14}$ That is, two food categories not inherently containing gluten, yet bearing the gluten-free label, accounted for over half of the gluten-free-food sales at the retail level in 2016. In turn, these effects are transferred to producers. Thus, in addition to observing significant decreases in average food product expenditures that inherently contain gluten, such as cereal and bakery foods, we have also observed significant changes in food expenditures for products not inherently containing gluten, such as meat, and the profits producers receive.

Gluten-free flexibility estimates indicate that meat producers have benefited from the popularity of gluten-free and the labeling requirements. Our estimates suggest meat producer welfare has increased by US\$3.7 billion/year. As outlined in the discussion under Scenario 2, a smaller portion of wheat and barley supply is (directly) allocated to food production and a larger portion to ani$\mathrm{mal} /$ livestock production to satisfy increases in meat demand. Consequently, any negative impacts wheat and barley producers would have incurred are outweighed by benefits attributed to shocks on other foods, such as meat, resulting in increased wheat and barley producer profits of US $\$ 14.5$ million/year.

Although the construction of the media index used in this study aligns with those used in previous studies, future studies might benefit from disaggregated, filtered media indexes. For instance, including product-specific indexes (e.g., search terms "gluten free" and "meat") along with an index that mentions no specific food categories might provide greater insight. However, this task is difficult when the "other" food category is included.

In short, the results presented in this study suggest expenditures on goods inherently containing gluten decreases as the popularity of gluten-free increases. This results in the redistribution of wheat and barley to aid in the production of substitutes for cereal and bakery food products, such

\footnotetext{
${ }^{14}$ Annual retail sales are based on a 52 week year ending 7/10/2016. The snacks segment includes a variety of naturally gluten-free products, potato chips and popcorn among them.
} 
as meat and food away from home. Whatever negative impacts have befallen wheat producers in recent years, this research suggests, somewhat unexpectedly, that rising interest in gluten-free food is not a major contributor, and may in fact have benefitted producers.

\section{References}

Adhikari, M., L. Paudel, J.E. Houston, K.P. Paudel, and J. Bukenya. "The Impact of Cholesterol Information on Meat Demand: Application of an Updated Cholesterol Index." Journal of Food Distribution Research 37,2(2006):60-69.

Alston, J.M. "Research Benefits in a Multimarket Setting: A Review." Review of Marketing and Agricultural Economics 59,1(1991):23-52.

Anderson, G.J., and R.W. Blundell. "Estimation and Hypothesis Testing in Dynamic Singular Equation Systems." Econometrica 50,6(1982):1559-72.

Anderson, G.J., and R.W. Blundell. "Testing Restrictions in a Flexible Dynamic Demand System: An Application to Consumers' Expenditure in Canada." The Review of Economic Studies 50,3(1983):397-410.

Atkins, R.C. Dr. Atkins Diet Revolution: The High Calorie Way to Stay Thin Forever. New York: D. McKay Co., 1972.

Atkins, R.C. Dr. Atkins' New Diet Regulation. Maryland, U.S.A: The Rowman \& Littlefield Publishing Group, Inc., 2002.

Aziz, I., M. Hadjivassiliou, and D.S. Sanders. "The Spectrum of Noncoeliac Gluten Sensitivity." Nature Reviews Gastroenterology and Hepatology 12,9(2015):516-26.

Berndt, E.R., and N.E. Savin. "Estimation and Hypothesis Testing in Singular Equation Systems with Autoregressive Disturbances." Econometrica 43,5-6(1975):937-57.

Brester, G.W., and T.C. Schroeder. "The Impacts of Brand and Generic Advertising on Meat Demand.” American Journal of Agricultural Economics 77,4(1995):969-79.

Brown, D.J., and L.F. Schrader. "Cholesterol Information and Shell Egg Consumption." American Journal of Agricultural Economics 72,3(1990):548-55.

Brown, M.G., Lee, J-Y., and J.L. Seale, Jr. “A Family of Inverse Demand Systems and Choice of Functional Form.” Empirical Economics 20,3(1995):519-30.

Burton, M., and T. Young. "The Impact of BSE on the Demand for Beef and Other Meats in Great Britain." Applied Economics 28,6(1996):687-93.

Chambers, R.G., and K.E. McConnell. "Decomposition and Additivity in Price Dependent Demand Systems." American Journal of Agricultural Economics 65,3(1983):596-602.

Chang, H.S., and H.W. Kinnucan. “Advertising, Information, and Product Quality: The Case of Butter." American Journal of Agricultural Economics 73,4(1991):1195-203.

Choung, R.K., A. Unalp-Arida, C.E. Ruhl, T.L. Branter, J.E. Everhart, and J.A. Murray. "Less Hidden Celiac Disease but Increased Gluten Avoidance without a Diagnosis in the United States: Findings from the National Health and Nutrition Examination Surveys from 2009 to 2014." Mayo Clinic Proceedings 92,1(2017):30-38.

Christensen, L.R., and M.E. Manser. "Estimating U.S. Consumer Preferences for Meat with a Flexible Utility Function." Journal of Econometrics 5,1(1977):37-53.

Davis, W. Wheat Belly. New York: Rodale Books, 2011.

Eales, J.S., and L.J. Unnevehr. “The Inverse Almost Ideal Demand System.” European Economic Review 38,1(1994):101-15.

Economic Research Service. New Products. Internet site: https://www.ers.usda.gov/topics/food-markets-prices/processingmarketing/new-products.aspx (Accessed February 27, 2018a).

Economic Research Service. Wheat's Role in the U.S. Diet. Internet site: https://www.ers.usda.gov/topics/crops/wheat/ wheats-role-in-the-us-diet.aspx (Accessed February 27, 2018b).

Economic Research Service. Wheat: Overview. Internet site: https:/www.ers.usda.gov/topics/crops/wheat.aspx? subject=CropsWheat (Accessed February 27, 2018c).

Economic Research Service. Wheat Data. Internet site: https://www.ers.usda.gov/data-products/wheat-data/ (Accessed March 2, 2018d).

Hicks, J.R. A Revision of Demand Theory. Oxford: Oxford University Press, 1956.

Holt, T.H., and B.K. Goodwin. "Generalized Habit Formation in an Inverse Almost Ideal Demand System: An Application to Meat Expenditures in the U.S.” Empirical Economics 22,2(1997):293-320.

Huang, K.S. “An Inverse Demand System for U.S. Composite Foods." American Journal of Agricultural Economics 70,4(1988):902-8.

Just, R.E. "Addressing the Changing Nature of Uncertainty in Agriculture." American Journal of Agricultural Economics 83,5(2001):1131-53.

Just, R.E., D.L. Hueth, and A. Schmitz. The Welfare Economics of Public Policy: A Practical Approach to Project and Policy Evaluation. Northhampton, MA: Elgar, 2005.

Kinnucan, H.W., H. Xiao, C.J. Hsia, and J.D. Jackson. "Effects of Health Information and Generic Advertising on U.S. Meat Demand." American Journal of Agricultural Economics 79,1(1997):13-23. 
Liu, S., J.C. Huang, and G.L. Brown. "Information and Risk Perception: A Dynamic Adjustment Process." Risk Analysis 18,6(1998):689-99.

Lusk, J.L. “Distributional Effects of Crop Insurance Subsidies.” Applied Economic Perspectives and Policy 39,1(2017):1-15.

Marsh, T.L., T.C. Schroeder, and J. Mintert. "Impacts of Meat Product Recalls on Consumer Demand in the USA." Applied Economics 39,9(2004):897-909.

Mazzocchi, M. "No News is Good News: Stochastic Parameters versus Media Coverage Indices in Demand Models after Food Scares." American Journal of Agricultural Economics 88,3(2006):727-41.

Miller, D.M. "Maybe It's Not the Gluten." Journal of the American Medical Association Internal Medicine 176,11(2016):171718.

Mintel Group Ltd. “Gluten-Free Foods, US-October 2016.” Market Data October 2016 US, pp. 16, 2016.

Moschini, G., and D. Moro. “Autocorrelation Specification in Singular Equation Systems.” Economic Letters 46,4(1994): 303-9.

National Agricultural Statistics Service (NASS). Internet site: https:/quickstats.nass.usda.gov/results/BBDC4961-83FA37B8-BB70-9775B757CA3A?pivot=short_desc (Accessed March 2, 2018).

National Institute of Diabetes and Digestive and Kidney Diseases. Definition \& Facts for Celiac Disease. Internet site: https://www.niddk.nih.gov/health-information/digestive-diseases/celiac-disease/definition-facts (Accessed April 1, 2017).

Navarro, C.J. “The Effect of Gluten-Free Labels on Customer's Perception of Healthiness, Expected Price, and Willingness to Purchase.” Ph.D. dissertation, Texas Christian University, 2016.

Okrent, A.M., and J.M. Alston. Demand for Food in the United States: A Review of Literature, Evaluation of Previous Estimates, and Presentation of New Estimates of Demand. Giannini Foundation, University of California, Monograph 28, April 2011.

Okrent, A.M., and J.M. Alston. The Demand for Disaggregated Food-Away-From-Home and Food-At-Home Products in the United States. Washington, DC: U.S. Department of Agriculture, ESCS For. Agr. Econ. Rep. 139, 2012.

Park, J., and O. Capps. "Impacts of Advertising, Attitudes, Lifestyles, and Health on the Demand for U.S. Pork: A Micro-Level Analysis." Journal of Agricultural and Applied Economics 34,1(2002):1-15.

Perlmutter, D.H. Grain Brain. New York: Little, Brown and Company, 2013.

Piggott, N.E., J.A. Chalfant, J.M. Alston, and G.R. Griffith. "Demand Response to Advertising in the Australian Meat Industry.” American Journal of Agricultural Economics 78,2(1996):268-79.

Piggott, N.E., and T.L. Marsh. “Does Food Safety Information Impact U.S. Meat Demand?” American Journal of Agricultural Economics 86,1(2004):154-74.

Piggott, N.E., and T.L. Marsh. "Constraint Utility Maximization and Demand System Estimation.” Oxford Handbook on the Economics of Food Consumption and Policy. J. Lusk, J. Roosen, and J. Shrogen,eds. Oxford, U.K.: Oxford University Press, 2010.

Reilly, N.R. "The Gluten-Free Diet: Recognizing Fact, Fiction, and Fad.” The Journal of Pediatrics 175(2016):206-10.

Rickertsen, K. “The Effects of Advertising in an Inverse Demand System: Norwegian Vegetables Revisited." European Review of Agricultural Economics 25,1(1998):129-40.

Rickertsen, K., D. Kristofersson, and S. Lothe. "Effects of Health Information on Nordic Meat and Fish Demand." Empirical Economics 28,2(2003):249-73.

Sears, J.P. How to Become Gluten Intolerant (Funny). Internet site: https://www.youtube.com/watch?v=Oht9AEq1798 (Accessed March 2, 2018).

Smith, M.E., E.O. van Ravenswaay, and S.R. Thompson. "Sales Loss Determination in Food Contamination Incidents: An Application to Milk Bans in Hawaii." American Journal of Agricultural Economics 70,3(1988):513-20.

Talley, N.J., and M.M. Walker. "Celiac Disease and Nonceliac Gluten or Wheat Sensitivity: The Risks and Benefits of Diagnosis." Journal of American Medical Association Internal Medicine 177,5(2016):615-16.

Tonsor, G.T., and N.J. Olynk. "Impacts of Animal Well-Being and Welfare Media on Meat Demand. Journal of Agricultural Economics 62,1(2011):58-72.

Tonsor, G.T., J.R. Mintert, and T.C. Schroeder. "U.S. Meat Demand: Household Dynamics and Media Information Impacts." Journal of Agricultural and Resource Economics 35,1(2010): 1-17.

U.S. Department of Commerce Bureau of Economic Analysis (BEA). Personal Consumption Expenditures by Type of Product with 2007 Input-Output Commodity Composition. Washington, DC: U.S. Department of Commerce Bureau of Economic Analysis, Table 2.4.5U-I-O, 2007.

U.S. Department of Commerce Bureau of Economic Analysis (BEA). Personal Consumption Expenditures by Type of Product. Washington, DC: U.S. Department of Commerce Bureau of Economic Analysis, Table 2.4.5U, 2017a.

U.S. Department of Commerce Bureau of Economic Analysis (BEA). Price Indexes for Personal Consumption Expenditures by Type of Product. Washington, DC: U.S. Department of Commerce Bureau of Economic Analysis, Table 2.4.4U, 2017b.

U.S. Department of Commerce Bureau of Economic Analysis (BEA). Consumer Spending. Internet site: https://www.bea. gov/data/consumer-spending/main (Accessed October 26, 2018).

U.S. Food and Drug Administration Health and Human Services Department (FDA, HHS). “Food Labeling: Gluten-free Labeling of Foods." Federal Register/78,150(2013). 
U.S. Food and Drug Administration. How to Understand and Use the Nutrition Facts Label. Internet site: https://www.fda. gov/food/nutrition-education-resources-materials/how-understand-and-use-nutrition-facts-label\#top (Accessed March 6, 2018).

Van den Wijngaart, A. "Nutrition Labelling: Purpose, Scientific Issues and Challenges." Asia Pacific Journal of Clinical Nutrition 11,2(2002):S68-S71.

Verbeke, W., and R.W. Ward. "A Fresh Meat Almost Ideal Demand System Incorporating Negative TV Press and Advertising Impact.” Agricultural Economics 25,2-3(2001):359-74.

Wohlgenant, M. "Consumer Demand and Welfare in Equilibrium Displacement Models." Oxford Handbook of the Economics of Food Consumption and Policy. J.L. Lusk, J. Roosen, and J. Shogren, eds. Oxford, U.K.: Oxford University Press, 2011, pp. 292-318.

Yadavalli, A., and K. Jones. "Does Media Influence Consumer Demand? The Case of Lean Finely Textured Beef in the United States." Food Policy 49,1(2014):219-27.

\section{Appendix A}

Table A1. Average annual price index

\begin{tabular}{|c|c|c|c|c|c|c|c|c|c|}
\hline Year & $\begin{array}{c}\text { Cereal and } \\
\text { Bakery }\end{array}$ & Meat & Dairy & Eggs & $\begin{array}{l}\text { Fruits and } \\
\text { Vegetables }\end{array}$ & $\begin{array}{l}\text { Food Away } \\
\text { from Home }\end{array}$ & $\begin{array}{l}\text { Alcoholic } \\
\text { Beverages }\end{array}$ & $\begin{array}{c}\text { Nonalcoholic } \\
\text { Beverages }\end{array}$ & $\begin{array}{l}\text { Other } \\
\text { Foods }\end{array}$ \\
\hline 2004 & 81.56 & 90.48 & 92.20 & 88.04 & 85.15 & 84.97 & 89.66 & 85.98 & 85.51 \\
\hline 2005 & 82.72 & 92.50 & 93.46 & 76.08 & 88.38 & 87.69 & 90.73 & 87.91 & 86.75 \\
\hline 2006 & 84.27 & 92.44 & 92.77 & 79.76 & 92.43 & 90.65 & 92.00 & 89.89 & 88.31 \\
\hline 2007 & 87.93 & 95.90 & 99.71 & 103.11 & 95.84 & 94.16 & 94.19 & 93.62 & 90.29 \\
\hline 2008 & 96.87 & 99.66 & 108.02 & 117.49 & 101.85 & 97.82 & 97.17 & 97.68 & 95.94 \\
\hline 2009 & 100.00 & 100.00 & 100.05 & 100.07 & 100.02 & 100.00 & 100.00 & 100.00 & 100.00 \\
\hline 2010 & 99.14 & 101.61 & 101.43 & 101.59 & 100.34 & 101.33 & 100.42 & 98.81 & 100.28 \\
\hline 2011 & 103.12 & 108.34 & 108.44 & 110.52 & 104.34 & 103.88 & 101.01 & 101.38 & 103.58 \\
\hline 2012 & 106.11 & 112.46 & 110.70 & 113.86 & 103.50 & 106.81 & 101.95 & 102.55 & 107.63 \\
\hline 2013 & 107.56 & 114.92 & 111.36 & 117.36 & 106.24 & 108.94 & 103.28 & 101.92 & 107.48 \\
\hline 2014 & 107.87 & 122.13 & 115.69 & 128.46 & 107.10 & 111.89 & 104.02 & 101.23 & 108.02 \\
\hline 2015 & 109.06 & 124.73 & 113.49 & 151.26 & 107.26 & 115.01 & 104.24 & 102.35 & 109.87 \\
\hline 2016 & 108.69 & 120.28 & 110.39 & 119.65 & 107.94 & 117.98 & 105.21 & 102.24 & 109.95 \\
\hline 2017 & 101.38 & 106.75 & 99.86 & 94.22 & 104.30 & 112.82 & 103.73 & 99.79 & 102.26 \\
\hline 2018 & 101.52 & 107.38 & 99.40 & 108.24 & 104.71 & 114.99 & 104.32 & 99.59 & 102.39 \\
\hline
\end{tabular}


Table A2. Average annual quantity index

\begin{tabular}{|c|c|c|c|c|c|c|c|c|c|}
\hline Year & $\begin{array}{c}\text { Cereal and } \\
\text { Bakery }\end{array}$ & Meat & Dairy & Eggs & $\begin{array}{l}\text { Fruits and } \\
\text { Vegetables }\end{array}$ & $\begin{array}{l}\text { Food Away } \\
\text { from Home }\end{array}$ & $\begin{array}{l}\text { Alcoholic } \\
\text { Beverages }\end{array}$ & $\begin{array}{c}\text { Nonalcoholic } \\
\text { Beverages }\end{array}$ & $\begin{array}{l}\text { Other } \\
\text { Foods }\end{array}$ \\
\hline 2004 & 97.50 & 100.10 & 42.99 & 6.69 & 69.62 & 486.80 & 82.97 & 65.21 & 132.94 \\
\hline 2005 & 101.03 & 104.03 & 44.57 & 8.36 & 72.04 & 504.21 & 85.00 & 67.96 & 138.23 \\
\hline 2006 & 103.83 & 106.27 & 47.15 & 8.73 & 71.83 & 520.53 & 88.97 & 70.46 & 143.79 \\
\hline 2007 & 104.32 & 107.49 & 48.00 & 7.75 & 72.97 & 527.13 & 90.43 & 70.82 & 148.10 \\
\hline 2008 & 101.22 & 108.56 & 47.33 & 7.29 & 72.67 & 521.81 & 89.81 & 70.10 & 145.31 \\
\hline 2009 & 98.28 & 108.70 & 48.74 & 8.08 & 74.49 & 500.28 & 88.45 & 67.03 & 138.64 \\
\hline 2010 & 100.34 & 109.47 & 49.03 & 8.11 & 76.38 & 507.99 & 93.43 & 68.44 & 140.82 \\
\hline 2011 & 101.76 & 108.16 & 49.65 & 8.06 & 77.94 & 521.03 & 96.55 & 69.15 & 142.18 \\
\hline 2012 & 101.07 & 105.88 & 49.24 & 7.89 & 80.76 & 534.53 & 99.81 & 69.26 & 140.33 \\
\hline 2013 & 102.16 & 99.55 & 49.77 & 7.77 & 82.97 & 543.75 & 99.49 & 68.83 & 144.25 \\
\hline 2014 & 103.23 & 99.34 & 49.87 & 7.38 & 84.76 & 561.52 & 102.58 & 70.04 & 146.77 \\
\hline 2015 & 103.93 & 94.42 & 51.68 & 6.40 & 86.90 & 585.52 & 106.80 & 70.89 & 148.06 \\
\hline 2016 & 105.43 & 98.19 & 52.82 & 8.07 & 87.64 & 599.83 & 109.84 & 72.35 & 152.72 \\
\hline 2017 & 114.69 & 133.60 & 60.15 & 11.02 & 87.97 & 662.78 & 109.06 & 77.34 & 177.05 \\
\hline 2018 & 118.67 & 136.86 & 62.14 & 9.87 & 89.86 & 676.50 & 111.98 & 79.53 & 181.79 \\
\hline
\end{tabular}

Table A3. Autocorrelation matrix of the Inverse Almost Ideal Demand System (IAIDS) model using monthly LexisNexis data $(k=1)$

\begin{tabular}{|c|c|c|c|c|c|c|c|c|}
\hline $\begin{array}{l}\text { Autocorrelation } \\
\text { Coefficient }\end{array}$ & $\begin{array}{c}\text { Cereal } \\
\text { and Bakery } \\
\qquad\left(\delta_{1, i 1}\right)\end{array}$ & $\begin{array}{l}\text { Meat } \\
\left(\delta_{1, i 2}\right)\end{array}$ & $\begin{array}{l}\text { Dairy } \\
\left(\delta_{1, i 3}\right)\end{array}$ & $\begin{array}{l}\text { Eggs } \\
\left(\delta_{1, i 4}\right)\end{array}$ & $\begin{array}{l}\text { Fruits and } \\
\text { Vegetables } \\
\left(\delta_{1, i 5}\right)\end{array}$ & $\begin{array}{l}\text { Food Away } \\
\text { from Home } \\
\qquad\left(\delta_{1, i 6}\right)\end{array}$ & $\begin{array}{c}\text { Alcoholic } \\
\text { Beverages } \\
\left(\delta_{1, i 7}\right)\end{array}$ & $\begin{array}{c}\text { Nonalcoholic } \\
\text { Beverages } \\
\left(\delta_{1, i 8}\right)\end{array}$ \\
\hline \multirow{2}{*}{$\begin{array}{l}\text { Cereal and bakery } \\
\left(\delta_{1,1 j}\right)\end{array}$} & 0.2256 & $-0.4411^{\star \star}$ & $0.7485^{\star}$ & -2.0243 & -0.1706 & $-0.2317^{\star \star}$ & -0.1610 & -0.2046 \\
\hline & $(0.1877)$ & (0.1110) & $(0.3322)$ & (1.1332) & $(0.1586)$ & $(0.0875)$ & $(0.1537)$ & $(0.2133)$ \\
\hline \multirow[t]{2}{*}{ Meat $\left(\delta_{1,2 j}\right)$} & -0.2502 & $0.9902^{\star \star}$ & -0.0311 & 1.1403 & -0.0697 & 0.0091 & -0.2589 & -0.2065 \\
\hline & $(0.2481)$ & $(0.1474)$ & $(0.4423)$ & (1.5147) & $(0.2110)$ & (0.1159) & $(0.2030)$ & $(0.2846)$ \\
\hline \multirow[t]{2}{*}{ Dairy $\left(\delta_{1,3 j}\right)$} & 0.0609 & -0.0706 & $1.1233^{\star \star}$ & 0.2264 & -0.1684 & 0.0185 & 0.0630 & -0.0152 \\
\hline & $(0.1340)$ & $(0.0796)$ & $(0.2381)$ & $(0.8142)$ & $(0.1136)$ & $(0.0627)$ & $(0.1095)$ & $(0.1533)$ \\
\hline \multirow[t]{2}{*}{ Eggs $\left(\delta_{1,4 j}\right)$} & -0.0183 & -0.0311 & 0.0622 & $0.9306^{\star \star}$ & -0.0641 & -0.0077 & -0.0196 & -0.0030 \\
\hline & $(0.0403)$ & $(0.0239)$ & $(0.0715)$ & $(0.2445)$ & $(0.0341)$ & $(0.0188)$ & $(0.0329)$ & $(0.0461)$ \\
\hline \multirow{2}{*}{$\begin{array}{l}\text { Fruits and } \\
\text { vegetables }\left(\delta_{1,5 j}\right) \\
\end{array}$} & -0.1472 & $-0.2458^{\star}$ & $0.6448^{\star}$ & -1.7583 & $0.6470^{\star \star}$ & -0.0944 & -0.2468 & -0.1898 \\
\hline & (0.1639) & $(0.0976)$ & $(0.2909)$ & (0.9938) & $(0.1386)$ & $(0.0765)$ & $(0.1339)$ & $(0.1870)$ \\
\hline \multirow[t]{2}{*}{$\begin{array}{l}\text { Food away from } \\
\text { home }\left(\delta_{1,6 j}\right)\end{array}$} & 0.9467 & 0.5778 & -1.8847 & 2.1754 & 0.3603 & $0.9815^{\star \star}$ & 0.6480 & 0.5040 \\
\hline & $(0.5767)$ & $(0.3433)$ & (1.0279) & (3.5207) & $(0.4911)$ & $(0.2698)$ & $(0.4707)$ & $(0.6628)$ \\
\hline
\end{tabular}


Table A3. (Continued)

\begin{tabular}{|c|c|c|c|c|c|c|c|c|}
\hline $\begin{array}{l}\text { Autocorrelation } \\
\text { Coefficient }\end{array}$ & $\begin{array}{c}\text { Cereal } \\
\text { and Bakery } \\
\left(\delta_{1, i 1}\right)\end{array}$ & $\begin{array}{l}\text { Meat } \\
\left(\delta_{1, i 2}\right)\end{array}$ & $\begin{array}{l}\text { Dairy } \\
\left(\delta_{1, i 3}\right)\end{array}$ & $\begin{array}{l}\text { Eggs } \\
\left(\delta_{1, i 4}\right)\end{array}$ & $\begin{array}{l}\text { Fruits and } \\
\text { Vegetables } \\
\left(\delta_{1, i 5}\right)\end{array}$ & $\begin{array}{l}\text { Food Away } \\
\text { from Home } \\
\qquad\left(\delta_{1, i 6}\right)\end{array}$ & $\begin{array}{c}\text { Alcoholic } \\
\text { Beverages } \\
\left(\delta_{1, i 7}\right)\end{array}$ & $\begin{array}{c}\text { Nonalcoholic } \\
\text { Beverages } \\
\left(\delta_{1, i 8}\right)\end{array}$ \\
\hline \multirow[t]{2}{*}{$\begin{array}{l}\text { Alcoholic beverages } \\
\left(\delta_{1,7 j}\right)\end{array}$} & -0.2147 & -0.0149 & -0.0562 & -0.6838 & 0.0412 & -0.0612 & $0.3863^{\star \star}$ & -0.1080 \\
\hline & $(0.1426)$ & $(0.0838)$ & $(0.2500)$ & $(0.8538)$ & $(0.1191)$ & $(0.0660)$ & $(0.1162)$ & $(0.1605)$ \\
\hline \multirow[t]{2}{*}{$\begin{array}{l}\text { Nonalcoholic } \\
\text { beverages }\left(\delta_{1,8 j}\right)\end{array}$} & -0.0139 & -0.0943 & -0.3397 & $1.5855^{\star}$ & -0.0989 & -0.0250 & -0.0011 & $0.5318^{\star \star}$ \\
\hline & $(0.1163)$ & $(0.0686)$ & $(0.2040)$ & $(0.6954)$ & $(0.0972)$ & $(0.0538)$ & $(0.0945)$ & $(0.1308)$ \\
\hline Diagnostic tests & Test statistic & & & & & & & \\
\hline $\begin{array}{l}\delta_{1,12}=\ldots \\
\delta_{1,23}=\ldots=\ldots \\
\delta_{1,87}=0\end{array}$ & $162.23^{\star \star}$ & & & & & & & \\
\hline $\begin{array}{l}\delta_{1,11}=\delta_{1,22}=\ldots= \\
\delta_{1,77}=\delta_{1,88}=0\end{array}$ & $2,094.00^{\star \star}$ & & & & & & & \\
\hline
\end{tabular}

* Statistical significance at the $5 \%$ level.

** Statistical significance at the $1 \%$ level.

Note: Standard errors are in parentheses.

Table A4. Autocorrelation matrix of the Inverse Almost Ideal Demand System (IAIDS) model using monthly LexisNexis data $(k=2)$

\begin{tabular}{|c|c|c|c|c|c|c|c|c|}
\hline $\begin{array}{l}\text { Autocorrelation } \\
\text { Coefficient }\end{array}$ & $\begin{array}{c}\text { Cereal and } \\
\text { Bakery } \\
\left(\delta_{2, i 1}\right)\end{array}$ & $\begin{array}{l}\text { Meat } \\
\left(\delta_{2, i 2}\right)\end{array}$ & $\begin{array}{l}\text { Dairy } \\
\left(\delta_{2, i 3}\right)\end{array}$ & $\begin{array}{l}\text { Eggs } \\
\left(\delta_{2, i 4}\right)\end{array}$ & $\begin{array}{l}\text { Fruits and } \\
\text { Vegetables } \\
\left(\delta_{2, i 5}\right)\end{array}$ & $\begin{array}{l}\text { Food Away } \\
\text { from Home } \\
\qquad\left(\delta_{2, i 6}\right)\end{array}$ & $\begin{array}{c}\text { Alcoholic } \\
\text { Beverages } \\
\left(\delta_{2, i 7}\right)\end{array}$ & $\begin{array}{c}\text { Nonalcoholic } \\
\text { Beverages } \\
\left(\delta_{2, i 8}\right)\end{array}$ \\
\hline \multirow[t]{2}{*}{$\begin{array}{l}\text { Cereal and bakery } \\
\left(\delta_{2,1 j}\right)\end{array}$} & 0.3298 & $0.2881^{*}$ & -0.6638 & 2.0236 & -0.0271 & 0.1134 & -0.0872 & -0.1397 \\
\hline & $(0.1892)$ & $(0.1145)$ & $(0.3418)$ & (1.1112) & $(0.1530)$ & $(0.0900)$ & (0.1593) & $(0.2225)$ \\
\hline \multirow[t]{2}{*}{ Meat $\left(\delta_{2,2 j}\right)$} & 0.0913 & -0.1397 & 0.4999 & -1.5595 & 0.2048 & -0.0024 & 0.3460 & -0.1219 \\
\hline & $(0.2514)$ & $(0.1517)$ & $(0.4512)$ & $(1.4736)$ & $(0.2031)$ & $(0.1200)$ & $(0.2110)$ & $(0.2959)$ \\
\hline \multirow[t]{2}{*}{ Dairy $\left(\delta_{2,3 j}\right)$} & 0.0774 & 0.1287 & -0.1160 & 0.2312 & 0.1412 & 0.0520 & 0.0515 & -0.0586 \\
\hline & $(0.1357)$ & $(0.0819)$ & $(0.2437)$ & $(0.7926)$ & (0.1099) & $(0.0647)$ & $(0.1141)$ & $(0.1596)$ \\
\hline \multirow[t]{2}{*}{ Eggs $\left(\delta_{2,4 j}\right)$} & 0.0371 & 0.0399 & -0.0489 & 0.0746 & 0.0594 & 0.0214 & 0.0273 & -0.0132 \\
\hline & $(0.0407)$ & $(0.0246)$ & $(0.0732)$ & $(0.2379)$ & $(0.0330)$ & $(0.0194)$ & $(0.0343)$ & $(0.0479)$ \\
\hline \multirow[t]{2}{*}{$\begin{array}{l}\text { Fruits and vegetables } \\
\left(\delta_{2,5 j}\right)\end{array}$} & 0.1544 & 0.2038 & -0.5555 & 1.6937 & 0.1291 & 0.0939 & 0.0990 & -0.0518 \\
\hline & $(0.1657)$ & (0.0999) & $(0.2988)$ & $(0.9728)$ & $(0.1349)$ & $(0.0790)$ & $(0.1404)$ & $(0.1955)$ \\
\hline \multirow[t]{2}{*}{$\begin{array}{l}\text { Food away from home } \\
\left(\delta_{2,6 j}\right)\end{array}$} & -0.4699 & -0.5181 & 0.8001 & -1.8707 & -0.3745 & -0.1621 & -0.5288 & 0.2992 \\
\hline & $(0.5852)$ & (0.3531) & $(1.0467)$ & (3.4115) & $(0.4735)$ & $(0.2794)$ & $(0.4924)$ & $(0.6892)$ \\
\hline \multirow[t]{2}{*}{$\begin{array}{l}\text { Alcoholic beverages } \\
\left(\delta_{2,7 j}\right)\end{array}$} & 0.0762 & -0.0701 & -0.2725 & 0.8520 & -0.0775 & -0.0291 & 0.2294 & -0.0198 \\
\hline & $(0.1432)$ & $(0.0863)$ & $(0.2578)$ & $(0.8408)$ & $(0.1155)$ & $(0.0679)$ & $(0.1205)$ & $(0.1680)$ \\
\hline
\end{tabular}


Table A4. (Continued)

\begin{tabular}{|c|c|c|c|c|c|c|c|c|}
\hline $\begin{array}{l}\text { Autocorrelation } \\
\text { Coefficient }\end{array}$ & $\begin{array}{c}\text { Cereal and } \\
\text { Bakery } \\
\left(\delta_{2, i 1}\right)\end{array}$ & $\begin{array}{l}\text { Meat } \\
\left(\delta_{2, i 2}\right) \\
\end{array}$ & $\begin{array}{l}\text { Dairy } \\
\left(\delta_{2, i 3}\right) \\
\end{array}$ & $\begin{array}{l}\text { Eggs } \\
\left(\delta_{2, i 4}\right) \\
\end{array}$ & $\begin{array}{c}\text { Fruits and } \\
\text { Vegetables } \\
\left(\delta_{2, i 5}\right) \\
\end{array}$ & $\begin{array}{c}\text { Food Away } \\
\text { from Home } \\
\left(\delta_{2, i 6}\right)\end{array}$ & $\begin{array}{c}\text { Alcoholic } \\
\text { Beverages } \\
\left(\delta_{2, i 7}\right) \\
\end{array}$ & $\begin{array}{c}\text { Nonalcoholic } \\
\text { Beverages } \\
\left(\delta_{2, i 8}\right)\end{array}$ \\
\hline \multirow{2}{*}{$\begin{array}{l}\text { Nonalcoholic } \\
\text { beverages }\left(\delta_{2,8 j}\right)\end{array}$} & -0.0553 & 0.0928 & $0.4561^{*}$ & $-1.4426^{*}$ & 0.1004 & 0.0373 & 0.0226 & $0.2876^{\star}$ \\
\hline & $(0.1168)$ & $(0.0705)$ & $(0.2117)$ & $(0.6878)$ & $(0.0941)$ & $(0.0554)$ & $(0.0987)$ & $(0.1373)$ \\
\hline Diagnostic tests & Test statistic & & & & & & & \\
\hline $\begin{array}{l}\delta_{2,12}=\ldots=\delta_{2,23} \\
=\ldots=\ldots \delta_{2,87}=0\end{array}$ & $81.94^{\star}$ & & & & & & & \\
\hline $\begin{array}{l}\delta_{2,11}=\delta_{2,22}=\ldots=\delta_{2,77} \\
=\delta_{2,88}=0\end{array}$ & $17.90^{\star}$ & & & & & & & \\
\hline
\end{tabular}

${ }^{*}$ Statistical significance at the $5 \%$ level.

${ }^{* \star}$ Statistical significance at the $1 \%$ level.Note: Standard errors are in parentheses.

Table A5. Annual gluten-free index and percentage change: 2004-2017

\begin{tabular}{|c|c|c|}
\hline Year & Gluten-Free Index & Percentage Change (\%) \\
\hline 2004 & 718 & - \\
\hline 2005 & 849 & 18.25 \\
\hline 2006 & 1,419 & 67.14 \\
\hline 2007 & 1,747 & 23.11 \\
\hline 2008 & 2,365 & 35.37 \\
\hline 2009 & 2,628 & 11.12 \\
\hline 2010 & 3,549 & 35.05 \\
\hline 2011 & 4,755 & 33.98 \\
\hline 2012 & 6,080 & 27.87 \\
\hline 2013 & 7,855 & 29.19 \\
\hline 2014 & 10,678 & 35.94 \\
\hline 2015 & 11,143 & 4.35 \\
\hline 2016 & 12,245 & 9.89 \\
\hline 2017 & 11,766 & -3.91 \\
\hline Average & 5,557 & 25.18 \\
\hline
\end{tabular}

\section{Appendix B}

\section{B1. Equilibrium displacement model}

The equilibrium displacement model used in this study is exactly the same as in Lusk (2017), with four exceptions: (1) the demand side of the model is rewritten as quantity-dependent and the flexibilities shown in Table 3 are used to parameterize demands; (2) shocks to the model are given by the gluten-free flexibilities shown in Table 4 multiplied by the assumed percentage change in articles about gluten; (3) the expenditure and value of production data used to calculate welfare estimates are updated, and (4) a slight modification is made to the consumer welfare calculation to ensure consistency with our demand estimates. 
Wohlgenant (2011) shows that the estimated change in compensating variation is

$$
\Delta C V_{i}=P_{i, 0} Q_{i, 0}\left(\hat{P}_{j}+\delta_{j}\right)\left(1+0.5 \sum_{j=1}^{9} \eta_{i j}^{*}\left(\hat{P}_{j}+\delta_{j}\right)\right),
$$

where $\eta_{i j}^{*}$ is the compensated elasticity of demand. We alter this formula in two ways. First, note that $\eta_{i j}^{*}\left(\hat{P}_{j}+\delta_{j}\right)$ is the utility-constant change in quantity; we replace this with the model output proportionate change in quantity, $\hat{Q}_{j}$. Second, note that $\delta_{j}$ is the proportionate demand shift in the price direction, which in our case is simply the gluten-free flexibility multiplied by the assumed proportionate change in media articles.

Updated data, averaged across years 2004-2017, for annual expenditures for each of the nine food products are provided in Table B2. Values of production used to calculate changes in producer surplus are also averaged across years 2004-2017 (when possible). Values are in Table B3.

Table B1. Compensated own- and cross-price gluten-free flexibilities using iterative seemingly unrelated regressions (ITSUR) estimates of the Inverse Almost Ideal Demand System (IAIDS) model with monthly data

\begin{tabular}{|c|c|c|c|c|c|c|c|c|c|}
\hline \multirow[b]{2}{*}{$\begin{array}{l}\text { With Respect } \\
\text { to }\end{array}$} & \multicolumn{9}{|c|}{ Price Flexibility for } \\
\hline & $\begin{array}{l}\text { Cereal } \\
\text { and } \\
\text { Bakery }\end{array}$ & Meat & Eggs & Dairy & $\begin{array}{l}\text { Fruits and } \\
\text { Vegetables }\end{array}$ & $\begin{array}{l}\text { Other } \\
\text { Foods }\end{array}$ & $\begin{array}{c}\text { Nonalcoholic } \\
\text { Beverages }\end{array}$ & $\begin{array}{c}\text { Food } \\
\text { Away from } \\
\text { Home }\end{array}$ & $\begin{array}{l}\text { Alcoholic } \\
\text { beverages }\end{array}$ \\
\hline $\begin{array}{l}\text { Cereal and } \\
\text { bakery }\end{array}$ & -0.5848 & 0.1020 & 0.1074 & 0.1584 & 0.2541 & -0.0633 & 0.1340 & 0.0425 & -0.0527 \\
\hline Meat & 0.1135 & -0.2846 & 0.0366 & 0.0868 & -0.0955 & 0.1015 & 0.0827 & -0.0181 & 0.1355 \\
\hline Eggs & 0.0089 & 0.0027 & -1.0236 & -0.0270 & 0.0245 & 0.0252 & 0.0259 & 0.0016 & 0.0052 \\
\hline Dairy & 0.0806 & 0.0397 & -0.1654 & -1.1561 & 0.1151 & 0.1096 & 0.1070 & 0.0119 & 0.0971 \\
\hline $\begin{array}{l}\text { Fruits and } \\
\text { vegetables }\end{array}$ & 0.1980 & -0.0669 & 0.2298 & 0.1763 & -0.7035 & 0.1001 & 0.0413 & 0.0188 & 0.0426 \\
\hline Other foods & -0.0912 & 0.1314 & 0.4368 & 0.3103 & 0.1851 & -0.4901 & -0.0986 & 0.0492 & 0.1147 \\
\hline $\begin{array}{l}\text { Nonalcoholic } \\
\text { beverages }\end{array}$ & 0.0907 & 0.0504 & 0.2109 & 0.1425 & 0.0359 & -0.0463 & -0.5715 & 0.0306 & 0.0215 \\
\hline $\begin{array}{l}\text { Food away } \\
\text { from home }\end{array}$ & 0.2339 & -0.0895 & 0.1086 & 0.1288 & 0.1329 & 0.1883 & 0.2492 & -0.1078 & -0.1682 \\
\hline $\begin{array}{l}\text { Alcoholic } \\
\text { beverages }\end{array}$ & -0.0497 & 0.1148 & 0.0589 & 0.1800 & 0.0515 & 0.0750 & 0.0299 & -0.0288 & -0.1956 \\
\hline
\end{tabular}


Table B2. Annual food expenditures (million US\$)

\begin{tabular}{|c|c|c|c|c|c|c|c|c|c|c|}
\hline Year & $\begin{array}{c}\text { Cereal } \\
\text { and } \\
\text { Bakery }\end{array}$ & Meat & Dairy & Eggs & $\begin{array}{l}\text { Fruits and } \\
\text { Vegetables }\end{array}$ & $\begin{array}{l}\text { Food } \\
\text { Away } \\
\text { from } \\
\text { Home }\end{array}$ & $\begin{array}{l}\text { Alcoholic } \\
\text { Beverages }\end{array}$ & $\begin{array}{c}\text { Nonalcoholic } \\
\text { Beverages }\end{array}$ & $\begin{array}{l}\text { Other } \\
\text { Foods }\end{array}$ & $\begin{array}{c}\text { Total } \\
\text { expenditures }\end{array}$ \\
\hline 2004 & 95,422 & 108,699 & 47,526 & 6,972 & 71,107 & 496,424 & 89,269 & 67,278 & 136,414 & $1,119,110$ \\
\hline 2005 & 100,292 & 115,470 & 49,986 & 7,625 & 76,395 & 530,641 & 92,551 & 71,694 & 143,906 & $1,188,559$ \\
\hline 2006 & 104,998 & 117,889 & 52,484 & 8,346 & 79,660 & 566,252 & 98,231 & 76,008 & 152,377 & $1,256,244$ \\
\hline 2007 & 110,079 & 123,688 & 57,353 & 9,548 & 83,913 & 595,634 & 102,215 & 79,557 & 160,464 & $1,322,450$ \\
\hline 2008 & 117,581 & 129,797 & 61,342 & 10,263 & 88,797 & 612,467 & 104,723 & 82,140 & 167,207 & $1,374,316$ \\
\hline 2009 & 117,932 & 130,412 & 58,499 & 9,698 & 89,389 & 600,334 & 106,138 & 80,438 & 166,364 & $1,359,204$ \\
\hline 2010 & 119,376 & 133,468 & 59,680 & 9,880 & 91,952 & 617,712 & 112,593 & 81,146 & 169,457 & $1,395,264$ \\
\hline 2011 & 125,897 & 140,590 & 64,582 & 10,683 & 97,580 & 649,505 & 117,036 & 84,121 & 176,705 & $1,466,698$ \\
\hline 2012 & 128,695 & 142,891 & 65,403 & 10,776 & 100,294 & 685,129 & 122,106 & 85,228 & 181,246 & $1,521,768$ \\
\hline 2013 & 131,851 & 137,283 & 66,509 & 10,944 & 105,770 & 710,827 & 123,313 & 84,174 & 186,032 & $1,556,702$ \\
\hline 2014 & 133,628 & 145,499 & 69,219 & 11,376 & 108,929 & 754,096 & 128,041 & 85,082 & 190,258 & $1,626,128$ \\
\hline 2015 & 136,018 & 141,318 & 70,373 & 11,519 & 111,847 & 808,152 & 133,586 & 87,070 & 195,210 & $1,695,093$ \\
\hline 2016 & 137,502 & 141,707 & 69,965 & 11,415 & 113,504 & 849,212 & 138,674 & 88,766 & 201,495 & $1,752,238$ \\
\hline 2017 & 139,516 & 171,133 & 72,073 & 12,442 & 110,090 & 897,294 & 135,757 & 92,610 & 217,260 & $1,848,175$ \\
\hline Average & 121,342 & 134,274 & 61,785 & 10,106 & 94,945 & 669,548 & 114,588 & 81,808 & 174,600 & $1,462,996$ \\
\hline
\end{tabular}


Table B3. Average annual values of production by commodity: 2004-2017 (million US\$)

\begin{tabular}{|c|c|}
\hline Commodity & Value of Production \\
\hline Vegetables and melon & $14,550.87$ \\
\hline Fruit and tree nuts & $27,606.80$ \\
\hline Sugarcane and beet & $2,591.27$ \\
\hline Peanuts & $1,089.20$ \\
\hline Fish & $17,287.00$ \\
\hline Marketing inputs & $16,980,807.17$ \\
\hline Cattle & $43,370.50$ \\
\hline Hogs & $16,963.01$ \\
\hline Dairy & $34,318.09$ \\
\hline Poultry & $31,001.31$ \\
\hline Eggs & $8,287.85$ \\
\hline Soybeans & $33,145.82$ \\
\hline Corn & $50,599.41$ \\
\hline Wheat & $11,487.74$ \\
\hline Rice & $2,653.11$ \\
\hline Barley & 896.29 \\
\hline Oats & 207.40 \\
\hline Sorghum & $1,410.42$ \\
\hline
\end{tabular}

Cite this article: Ates AM and Lusk JL (2020). Gluten-Free: Where's the Beef? Journal of Agricultural and Applied Economics 52, 308-334. https://doi.org/10.1017/aae.2020.1 